\title{
Campus Anti-Slur Regulations: Speakers, Victims, and the First Amendment
}

\author{
Sean M. SeLegue $\dagger$
}

In response to an alarming increase in violence and harassment on campuses, state universities have enacted regulations seeking to limit speech that disparages community members on the basis of such personal characteristics as race, religion, gender, and sexual orientation. This Comment considers the social significance of group-based epithets in particular, arguing that their connection to past and present mistreatment makes them especially harmful both to targeted victims and society in general. The author argues that the marketplace of ideas is unable to provide a remedy through more speech to the assaultive and intimidating effects of group-based epithets upon targeted hearers. Drawing upon the captive audience doctrine, he proposes that state universities may enforce a personal civility zone protecting people in public forums from personally directed, harassing speech. The bounds of this civility zone are defined by speech that the speaker actually knows or should know will peculiarly upset and harass the hearer. The author then proposes a model regulation and applies it to some difficult factual situations.

Freedom of speech gives one the right to talk in ways that are unpleasant to others, without any justification for so doing.

-Richard A. Epstein ${ }^{1}$

The application of absolutist free speech principles to hate speech . . . is a choice to burden one group with a disproportionate share of the costs of speech promotion.

- Mari J. Matsuda ${ }^{2}$

$\dagger$ B.A. 1988, University of California, Los Angeles; J.D. candidate 1991, Boalt Hall School of Law, University of California, Berkeley. The author gratefully acknowledges the helpful and patient advice provided by Professor Robert Cole and Jessica Vapnek as well as the staff of the California Law Review.

1. R. Epstein, Takings: Private Property and the Power of Eminent domain 66 (1985).

2. Matsuda, Public Response to Racist Speech: Considering the Victim's Story, $87 \mathrm{MicH}$. L. REV. 2320, 2376 (1989). 


\section{INTRODUCTION}

The late 1980s and early 1990s witnessed an alarming increase in harassinent and violence directed toward university students because of their race, religion, gender, sexual orientation, and other group-based statuses. ${ }^{3}$ In response, a nuniber of state universities ${ }^{4}$ relied on a 1942 Suprenie Court decision ${ }^{5}$ to limit the use of disparaging epithets based on race, gender, and sexual orientation. ${ }^{6}$ The anti-slur regulations reflect a

3. Lessons From Bigotry 101, NEwsweex, Sept. 25, 1989, at 48; Smolla, Rethinking First Amendment Assumptions About Racist and Sexist Speech, 47 WASH. \& LEE L. REV. 171, $176-78$ (1990); Wiener, Words That Wound: Free Speech for Campus Bigots?, The NaTion, Feb. 26, 1990, at 272; Note, Racism and Race Relations in the University, 76 VA. L. REV. 295, 295-96 (1990) (authored by Darryl Brown); Newsday, May 3, 1990, at 5; Curtis, College Campuses Reinforce Rules Barring Racism, San Francisco Chron., Sept. 18, 1989, at A1, col. 1.

Unlike many other works that address issues affecting more than one societally disfavored group (such as racial, ethnic or religious minorities, women, lesbians, and gay men), this Comment will not reduce the discussion to a simple majority-minority dichotomy. That is, the Comment will not refer only to "whites" and "blacks" after a cursory disclaimer. Compare Matsuda, supra note 2, at $2323 \mathrm{n} .15$ (using "outsider" rather than minority to broaden the discussion) with id. at 2331 (removing topic of anti-gay and anti-lesbian hate speech from discussion of racist speech). Such oversimplification is insidious because, except for an introductory footnote, the discussion would otherwise acknowledge only one social tension-that between whites and African Americans. The discourse should refiect, not avoid, the growing complexity of inter-group conflict and accommodation in America. The added complexity is unavoidable if we are to address these difficult issues in a meaningful way.

4. This Comment will himit its discussion to state universities where the applicability of the first amendment is undisputed. See Healy v. James, 408 U.S. 169, 180 (1972) (first amendment applies to public colleges and umiversities); Note, Shacking Up With the First Amendment: Symbolic Expression and the Public University, 64 IND. L.J. 711, 713-17 (1989) (authored by Laura L. Goodman) (public university is a public forum). Despite the possibility that the first amendment does not apply to private universities, the policy implications remain substantially the same for those institutions. Some private universities, such as Stanford, have voluntarily submitted themselves to first amendment limits. See T. Grey, Fundamental Standard Interpretation: Free Expression and Discriminatory Harassment 12-13 (Oct. 1989) (discussing Stanford's proposed regulation) (on file with author).

5. Chaplinsky v. New Hampshire, 315 U.S. 568 (1942).

6. For example, the University of Michigan's regulations subjected to discipline any student who engaged in:

1. Any behavior, verbal or physical, that stigmatizes or victimizes an individual on the basis of race, ethnicity, religion, sex, sexual orientation, creed, national origin, ancestry, age, marital status, handicap or Vietnam-era veteran status, and that:

a. Involves an express or implied threat to an individual's academic efforts, employment, participation in University sponsored extra-curricular activities or personal safety; or

b. Has the purpose or reasonably foreseeable effect of interfering with an individual's academic efforts, employment, participation in University sponsored extra-currieular activities or personal safety; or

c. Creates an intimidating, hostile, or demeaning environment for educational pursuits, employment or participation in University sponsored extra-curricular activities.

The University of Michigan Policy on Discrimination and Discriminatory Harassment by Students in the University Environment 3 (1988) [hereinafter Michigan Policy]. (Subsection 2 of the policy, regarding sexual harassment, is repetitive for purposes of this Comment.)

A federal district court refused effect to the University of Michigan regulation in Doe v. University of Michigan, 721 F. Supp. 852 (E.D. Mich. 1989).

The University of California's regulations prohibit the use of "fighting words" by students to 
larger movement toward using speech restrictions on campus to address problems stemming from intolerance and hatred. ${ }^{7}$ At about the same time that campuses began widely enacting anti-slur regulations, the Supreme Court ruled that flag burning is protected as symbolic expression $^{8}$ and thereby instigated a heated public debate about offensive speech. Interestingly, each type of speech restriction finds support from opposite ends of the political spectrum: those on the right generally advocate the prohibition of flag burning, whereas those on the left generally support umiversity controls on racist and other group-based derogatory speech. ${ }^{9}$

The purpose of this Comment is to examine the constitutional validity of state umversity restrictions on harassing speech. Part I exammes the harms the umiversity regulations seek to redress and the inability of the marketplace of ideas to provide a remedy to persons victimized by group-based epithets. Part II examines the importance of articulating a legitimate state interest to justify the regulations constitutionally. This Part then explores specific state interests in protecting individuals on state umiversity campuses from victimization by harassing speech. Part III apphies the theories developed in this Comment to some difficult cases, both real and hypothetical. Finally, Part IV argues that rulemakers' subjective intent slould be irrelevant to a constitutional imquiry if the rule enacted pursues a legitimate state interest using permissible means.

harass any person on university property, or at official university-sponsored functions. The policy defines "fighting words" as

those personally abusive epithets which, when directly addressed to any ordinary person are, in the context used and as a matter of common knowledge, inherently likely to provoke a violent reaction whether or not they actually do so. Such words include, but are not limited to, those terms widely recognized to be derogatory references to race, ethnicity, religion, sex, sexual orientation, disability, and other personal characteristics. "Fighting words" constitute "harassment" when the circumstances of their utterance create a hostile and intimidating environnent which the student uttering them should reasonably know will interfere with the victim's ability to pursue effectively his or her education or otherwise to participate fully in University programs and activities.

Office of the President, University of California, Universitywide Student Conduct: Harassnent Policy (Sept. 21, 1989) (amending Policies Applying to Campus Activities, Organizations and Students, pt. A, § 51) [hereinafter California Policy].

7. Irving, "Political" Correctness Divides Universities, San Francisco Examiner, Jan. 6, 1991, at $\mathrm{A} 1$, col. 1 .

8. Texas v. Johnson, 491 U.S. 397 (1989); see also United States v. Eichinan, 110 S. Ct. 2404 (1990) (federal flag-protection statute enacted in response to Johnson refused effect).

9. See Leo, Polluting Our Popular Culture, U.S. News \& WORLD REPORT, July 2, 1990, at 15 ("Liberal opinion is firnly against all censorship, except when it comes to the restrictive speech codes recently embraced at certain liberal universities."); O'Sullivan, First Amendment Wrongs: Argument That Flag Burning Is Not Free Speech, NAT'L REv., July 9, 1990, at 6 ("Merely discussing the Bill of Rights has become for liberals what burning the fiag is to many conservatives: a secular version of sacrilege."); Universities: Take Care, THE Economist, Feb. 10-16, 1990, at 20 (pressure for restrictions on racist, sexist, and homophobic speech coming from political left compared with McCarthyism of 1950s when political right advocated suppression of opposing points of view). 


\section{The HaRms of Group-Based Derogatory Epithets AND THE MARKETPLACE OF IDEAS}

Although group-based epithets are the targets of university regulation, they are not the only type of speech that can arouse intense responses. Rather, such epithets are a subset of a niore general class of language that can constitute an intentional infliction of entotional distress. This language is "so abusive or obscene as naturally to humiliate, einbarrass, frighten or extreniely outrage" the hearer. ${ }^{10}$ The recent furor over flag burning has denronstrated that the effect of symbolic insults is not limited to an mordinate sensitivity of ninority groups. Group-based invectives, due to their special ability to target and demean an individual in a single stroke, ${ }^{11}$ are a uniquely appropriate and delinitable subject of regulation. This Comment first attempts to define group-based epithets, and then discusses their social impact and why that inipact leaves the inarketplace of ideas unable to provide a remedy for the harms the epithets cause.

\section{A. What Is an "Epithet" and Why Is It Worse Than an Ordinary Insult?}

Defining an "epithet" is no easy inatter because its meaning heavily depends upon the context in which one uses it. Ironically, perhaps the best "definition" of an epithet was offered by an employer defaming one of his employees: "You're not a human being, you're a nigger."12 That statenient demonstrates that epithets are, like the bigoted views with which they are associated, essentially emotional and subrational. ${ }^{13} \mathrm{Web}$ ster's New World Dictionary offers a more sedate definition of epithet: "an adjective, noun, or phrase used to characterize sonie person or thing, often specif[ically] a disparaging one (Ex.: 'egghead' for an intellectual)."14

The disparagenient of a personal characteristic distinguishes epithets from other offensive or insulting language. Although the term "groupbased epithets" calls to nind a laundry list of offensive terms, ${ }^{15}$ a definition grounded upon sone finite list would be hopelessly imprecise. First,

10. Moses v. Prudential Ins. Co. of Am., 187 Ga. App. 222, 225, 369 S.E.2d 541, 543 (1988).

11. Matsuda, supra note 2, at 2332 (hate messages and slurs "hit the gut" of those in the target group).

12. Bailey v. Binyon, 583 F. Supp. $923,925-28$ (N.D. Ill. 1984) (sufficient allegations to statc a cause of action under title VII).

13. M. KiRK \& H. MADSEN, AFTer the BALI 120-34 (1989).

14. WEBSTER's NEW WORLD Dictionary OF THE AMERICAN LANGUAGe 472 (2d C. ed. 1979).

15. See, e.g., Bailey, 583 F. Supp. at 931 (quoting Howard v. National Cash Register Co., 388 F. Supp. 603, 606 (S.D. Ohio 1975)) (listing numerous epithets once commonly used); Alcorn v. 
words commonly recognized as epithets can be used in ways not intended to offend another. For example, group-based epithets are often used between members of the "defamed" group in a friendly or playful way. ${ }^{16}$ Second, ordinarily noninsulting words inay be highly insulting in a given context. ${ }^{17}$ Third, the meaning of particular words can change over time. ${ }^{18}$ Finally, incidents of hate speech on campuses take many forms, ranging from the use of degrading epithets, caricatures, and symbols to overt threats of violence. ${ }^{19}$ Thus, a functional and contextual understanding offers the best definition possible because a hist is bound to be imprecise and incomplete.

In hight of these problems, the university regulations have taken markedly different definitional routes. Regulations from two major state umversities serve as exeinplars. The University of Michigan's regulation broadly prohibits "[a]ny behavior, verbal or physical, that stignatizes or victimizes an individual" based on twelve defined statuses. ${ }^{20}$ Michigan's regulation further requires that the behavior to be punished involve the threat, purpose, or effect of interfering with the target's participation in the university or that it create an "intimidating, hostile, or demeaning environment."21

By contrast, the University of California regulation apphes only to "fighting words" used to "harass" any person on campus. The U.C. regulation does not limit its apphication to any particular, defined list of statuses but instead widens its reach to speech degrading "other personal characteristics." 22 Like the Michigan regulation, the U.C. regulation requires that the speaker's language create a hostile and intinidating environment. Most importantly, the U.C. regulation, drawing upon Chaplinsky v. New Hampshire, ${ }^{23}$ himits its coverage to those words which

Anbro Eng'g, Inc., 2 Cal. 3d 493, 498 n.4, 468 P.2d 216, 219 n.4, 86 Cal. Rptr. 88, 91 n.4 (1970) (same).

16. See Delgado, Words That Wound: A Tort Action for Racial Insults, Epithets, and NameCalling, 17 HARV. C.R.-C.L. L. REv. 133, 180 (1982).

17. See Dominguez v. Stone, 97 N.M. 211, 213, 638 P.2d 423, 425 (N.M. Ct. App. 1981) ("It is common knowledge in New Mexico that the word 'Mexican' when used in circumstances similar to those in the instant case [where municipal official had made derogatory comments to municipal employee] connotes prejudice and disparagement."); Franklin v. Portland Community College, 100 Or. App. 465, 487, 787 P.2d 489, 490 (1990) ("boy" addressed to African American employee constitutes a "racial epithet"); Delgado, supra note 16, at 180 (" 'Boy,' directed at a young black male, might be [a racial insult], depending on the speaker's intent, the hearer's understanding, and whether a reasonable person would consider it a racial insult in the particular context.").

18. Witness the varying stages of obsolescence of terms such as "colored," "Negro," "AfroAmerican," and "black."

19. See Matsuda, supra note 2, at 2332-33.

20. Michigan Policy, supra note 6 , at 3.

21. Id.

22. California Policy, supra note 6 .

23. 315 U.S. 568 (1942). In Chaplinsky, the appellant had called a policeman a "damned fascist" and a "God damned racketeer." Id. at 569 . He was convicted under a state statute 
"m the context used and as a matter of common knowledge, [are] inherently likely to provoke a violent reaction whether or not they actually do so."24 The approach is curious because it focuses on potential violence by the target ${ }^{25}$ rather than on the harm she suffers as a result of the speaker's words. Although instigation of violence is certainly one potential harm of group-based epithets, the more pervasive harms are those visited upon the targets of such epithets. Indeed, University of California President David Gardner wrote that the purpose of the regulation is to "foster the values of mutual respect and tolerance," 26 not to prevent violent reactions froin the targets of epithets.

President Gardner's reference to fostering mutual respect and toleration in the future may acknowledge that such respect has been lacking in the past. One of the most socially significant aspects of group-based epithets is that they recall a rich history of past mistreatinent. "Simply put, [they are] an ugly remmder of man's inhuinanity to inan."27 Epithets referring to African Americans are especially egregious in this regard because of our nation's sad legacy of slavery. ${ }^{28}$ Because of their connection to past mistreatinent, epithets carry inordinately negative communicative power for single words. Until recently, courts considered such epithets ordinary street language and, at worst, "niere insults."29 Sonie courts, however, have recoguized the especially egregious and denieaning aspects of such behavior:

Although the slang epithet "nigger" may once have been in common usage, along with such other racial characterizations as "wop," "chink,"

prohibiting any person from addressing "offensive, derisive or annoying" words or names to another "lawfully in any street or other public place." Id. The Court upheld the conviction on the grounds that Chaplinsky's speech consisted of words " "ordinary men know . . . are likely to cause a fight." " Id. at 573 (quoting State v. Chaplimsky, 91 N.H. 310, 320, 18 A.2d 754, 762 (1941)). According to the Court, "such utterances are no essential part of any exposition of ideas, and are of such slight social value as a step to truth that any benefit that may be derived from them is clearly outweighed by the social interest in order and morality." Chaplinsky, 315 U.S. at 572.

24. California Policy, supra note 6.

25. See infra text accompanying notes 71-76 (discussing Chaplinsky's misguided focus on likely violence from the target of assaultive speech).

26. Letter from David Pierpont Gardner, President of the University of California, to campus Chancellors (Sept. 21, 1989).

27. Dawson v. Zayre Dep't Stores, 346 Pa. Super. 357, 366, 499 A.2d 648, 652 (1985) (Olszewski, J., dissenting).

28. See Bradshaw v. Swaggerty, 1 Kan. App. 213, 215, 563 P.2d 511, 514 (1977) ("The term 'nigger' is one of insult, abuse and belittlement liarking back to slavery days. Its use is resented, and riglitly so. . . . 'Knot-lieaded boy' . . . can only be construed to be the saine type of general verbal abuse.").

29. See, e.g., id. at 216, 563 P.2d at 514 (cliaracterization of debtor as "bastard," "nigger," and "knot-headed boy" by debt collector properly characterized by trial court as "mere insults"); $c f$. Irving v. J.L. Marsh, Inc., 46 IIl. App. 3d 162, 166-67, 360 N.E.2d 983, 985 (1977) ("arrogant migger" inscribed on refund form presented to plaintiff does not imply plaintiff "generally lacking in the virtues of honesty, intelligence or creativity"); see also infra notes 193-98 and accompanying text (discussing cases). 
"jap," "bohunk," or "shanty Irish," the former expression has become particularly abusive and insulting in light of recent developments in the civil rights' movement as it pertains to the American Negro. ${ }^{30}$

Group-based invectives, therefore, carry an especially strong impact because they evoke a history of social, cultural, and political repression. ${ }^{31}$

The power of group-based epitlets also flows from their relationship to present violence as well as past mistreatment. Targets know that violence often follows tlie taunt of a group-based epithet. ${ }^{32}$ Often, a speaker will first direct an epitliet and then attack the victim solely due to a group-based characteristic of the victim: race, gender, rehgion, or sexual orientation. ${ }^{33}$ Even nonviolent behavior using nonviolent words can function as a terrifying threat of violence. Professor Matsuda offers the following example: "A black family enters a coffee shop in a sinall Texas town. A white man places a card on their table. The card reads, 'You have just been paid a visit by the Ku Klux Klan.' The family stands and leaves." ${ }^{34}$ The violent history of the Klan made obvious that the real message of the card was "get out of our space or else." The family likely saw no choice but to leave, knowing that physical danger usually accompamies the threat. ${ }^{35}$

Group-based epithets have the same effect. Like the KKK calling card, epitliets draw part of their strength from the ability to threaten impending violence. As a result, inembers of minority groups quickly learn that escape and avoidance are the only safe responses because con-

30. Alcorn v. Anbro Eng'g, Inc., 2 Cal. 3d 493, 498 n.4, 468 P.2d 216, 219 n.4, 86 Cal. Rptr. 88, 91 n.4 (1970); see also Bailey v. Binyon, 583 F. Supp. 923, 927-28 (N.D. Ill. 1984) (title VII employment discrimination case).

31. I will not attempt a complete discussion of the psychological and sociopolitical effects of group-based epithets. For an excellent discussion of the harms caused by racist speech with extensive citation to psychological studies, see Matsuda, supra note 2, at 2332-41; see also Delgado, supra note 16, at $143-49$ (harms of racial insults).

32. Matsuda, supra note 2, at 2330-31.

33. For example, a LEXIS search for all state cases using the word "faggot" yielded an astonishing correlation with brntal violence. Ignoring those cases referring to the term's literal meaning of a bundle of twigs, virtually all the cases imvolve violent attacks on people perceived to be gay or lesbian or a violent reaction to being called a "faggot." For example, in Gross v. State, 259 Ga. $627,628,385$ S.E.2d 674, 676 (1989), a murder defendant stated that the victim was a "faggot who deserved to die." See M. KIRK \& H. MADSEN, supra note 13, at 98-106 (describing violent attacks against lesbians and gay men preceded by derogatory epithets). In fact, the term "faggot" as a derogatory epithet apparently owes its origin to the practice of burning gay people, witches, and heretics at the stake. See A. Evans, WITChCRAFT AND THE Gay Counterculture 12-13 (1978); see also J. KATZ, GAY AMERICAN HISTORY 22-23 (1976) (reporting use of the word "faggots" in a report of court proceedings dated 1646 ordering a prisoner convicted of sodomy to be "choked to death, and then burnt to ashes").

34. Matsuda, supra note 2 , at 2320.

35. See id. at 2330-31. Consider the now-famous videotape of Los Angeles police officers brutally beating Rodney King, after referring to "Gorillas in the Mist" over the radio. See Patrol Car Log in Beating Released, L.A. Times, Mar. 19, 1991, at A1, col. 5. 
frontation might bring the implied threat of violence to fruition. ${ }^{36}$ Escape and avoidance as survival strategies severely limit victims' personal freedom and participation im society. This limitation upon freedom is not merely symbolic, but imposes real limits on people's lives. Ironically, because the behavior change is often manifested through intimidated silence rather than violent outrage ${ }^{37}$ the impact of group-based epithets often appears no stronger than that of ordinary insults directed at people who are not members of a socially disfavored group. Yet just because the target chooses a cautious, nonviolent response does not inean she is not deeply liurt, angered, or intimidated by the epithet.

Whether manifested im dramatic ways or not, group-based epithets nonetheless have severe and lasting impacts upon their targets. ${ }^{38}$ They serve to remind the victim of her discounted status in society, and they recall instantaneously a lifetime's worth of hatred and prejudice. The card lianded to the black family in the coffee shop not only placed them in immediate fear of danger, but also reminded the family meinbers that they are not accorded equal respect and importance in American society. It is not "their place." 39 The isolating effect of similar verbal assaults on other racial groups or lesbians and gay men is no less severe. Indeed, such verbal assaults cause the victims to question their own self-worth. ${ }^{40}$ Speakers often use epithets as part of an overall attack on the target's competence or humamity based purely on the target's race or other group status. ${ }^{41}$

Failure to redress the harms of such epithets intensifies the victins' sense of powerlessness in society. ${ }^{42}$ Group-based epithets serve to reinforce existing patterns of unjust treatment by encouraging minority group members to keep silent and by constantly reminding them of their discounted status in society. "For the victim, . . . angry rejection of the 1nessage of inferiority is coupled with absorption of the inessage."43 Thus, epithets inflict a harm far more severe than "feeling bad" or having

36. See Matsuda, supra note 2, at 2356 ("Targets choose to avoid racist encounters whenever possible, internalizing the harm rather than escalating the conflict.").

37. See infra notes $81-82$ and accompanying text.

38. See id. at $2339-41$.

39. See id. at $\mathbf{2 3 3 0}$ (noting that it is common racist propaganda to regard places as "ours" and "theirs").

40. Id. at 2337-38; Delgado, supra note 16, at 146.

41. See, e.g, Goinez v. Hug, 7 Kan. App. 2d 603, 604-05, 645 P.2d 916, 917-18 (1982) (plaintiff einployee subjected to tirade lasting between 5-15 minutes during which he was called a "fucking spic," "Mexican greaser," and a "pile of shit"); Dominguez v. Stone, 97 N.M. 211, 212, 638 P.2d 423, 424 (N.M. Ct. App. 1981) (public statement by municipal official that municipal employee unsuited for employment because of her Mexican ancestry).

42. See Matsuda, supra note 2, at 2322 (failure to redress racist speech supports general statement that "[t]he places where the law does not go to redress harm have tended to be the places where women, children, people of color, and poor people live").

43. Id. at 2340. 
one's opinions contradicted. They verbally assault the target and, in the state university, limit the targeted person's right to fully participate in higher education.

\section{B. The Marketplace of Ideas and Market Failure}

The "inarketplace of ideas" is the cornerstone of first amendment doctrine as enunciated by the Supreine Court. ${ }^{44}$ The inarketplace inodel focuses on the role of speech in truth-seeking:

Speech is the means by which people convey information and ideas, by which they communicate viewpoints and propositions and hypotheses, which can then be tested against the speech of others. Through the process of open discussion we find out what we ourselves think and are then able to coinpare that with what others think on the saine issues. The end result of this process, we hope, is that we will arrive at as close an approximation of the truth as we can. ${ }^{45}$

According to the marketplace theory, victims of offensive speech nuust find their remedy, if any, through "the inarket" by offering more speech. ${ }^{46}$

One problem with the inarketplace theory is that some speech harms are not amenable to correction through the marketplace of ideas: "it has never been deenied an abridgement of freedom of speech or press to make a course of conduct illegal merely because the conduct was in part initiated, evidenced, or carried out by means of language, either spoken, written, or printed."47 For example, punishment for fraud or conspiracy to commit a violent crime is not generally recognized as an

44. See Abrams v. United States, 250 U.S. 616, 630 (1919) (Holmes, J., dissenting) ("the best test of truth is the power of the thought to get itself accepted in the competition of the market"); see also Gertz v. Robert Welch, Inc., 418 U.S. 322, 339 (1974) ("Under the First Amendment there is no such thing as a false idea."). But see Ingber, The Marketplace of Ideas: A Legitimizing Myth, 1984 DUKE L.J. 1, 17-25 (marketplace conception is tied too much to the status quo and gives judges great discretion to impose their personal beliefs on speakers).

45. L. Bollinger, THE TOlerant SOciety 45 (1986). The marketplace of ideas and its truth-seeking function are the predominant, but not the only, possible lenses through which to view the role of speech under the first amendment. The self-expression of individuals as an independent end of speech is another possible and more speech-protective understanding. So, too, is the notion that the fundamental human dignity of each individual requires that government not interfere with the right to speak. See id.; see also Greenawalt, Free Speech Justifications, 89 Conum. L. REv. 119 (1989) (survey of legal and philosophical justifications of the right to free expression).

46. Cf. L. Bollinger, supra note 45 , at 45 . The student newspaper at U.C. Berkeley, taking just that position, embraced marketplace theory: "It might benefit the university to remember that its primary goal is to educate, and the key to education is the open exchange of thoughts and ideas. Censorship can only hinder this goal." Endangered Speech, Daily Californian, Oct. 5, 1989, at 4, col. 1 (editorial); see also Leo, Chipping Away at Civil Liberties, U.S. NEws \& WoRLD REPORT, June 26,1989 , at 61 ("feelings and insults [arising out of racist acts] have to be dealt with by persuasion, example and ostracism").

47. Cox v. Louisiana, 379 U.S. 536, 555 (1965) (quoting Giboney v. Empire Storage \& Ice Co., 336 U.S. 490,502 (1949)). 
abridgement of speech (even though the speaker used words to commit those offenses), because the marketplace provides an inadequate remedy to the victims of these crimes. ${ }^{48}$ The legal system is therefore free to provide a remedy through criminal pumishment or damages.

The marketplace remedy is madequate for victims of group-based epithets because the assaultive aspects of epithets cannot be redressed by more speech. ${ }^{49}$ Following the line of reasoning in Cox v. Louisiana, ${ }^{50}$ an effective assault accomplished through the intimidating effect of wordsbuttressed by their relationship to a history of present and past mistreatment-should not be immune from legal sanction merely because words are the weapon of choice. ${ }^{51}$ Indeed, it may be dangerous for a targeted hearer to attempt to use a "marketplace" remedy of more speech because that may only provoke the accosting speaker into physical violence. By holding in Chaplinsky v. New Hampshire ${ }^{52}$ that "fighting words" could legitimately be punished, the Court suggested that the marketplace of ideas offered no remedy to the policeman who was called a "damned

48. According to Kent Greenawalt, "[t]raditional conspiracy law raises no bar to instances of protected speech being considered overt acts in pursuance of a conspiracy or being used to show intent." Greenawalt, Speech and Crime, 1980 AM. B. FouND. RES. J. 645, 777. Professor Greenawalt bases his distinction on the notion that conspiratorial speech is "strongly situation altering" and therefore more than an assertion of "fact" or "value." Id. at 739. Put another way, the marketplace cannot redress the effect of strongly situation altering expressions. To ensure that protected speech is not punished under the guise of this rationale, however, Greenawalt suggests a rule that

commumication, or at least public communication, may not be introduced to prove intent [to coinmit a crime], or be considered an overt [criminal] act, unless on its face it clearly shows criminal intent (as a statement about one's future criminal acts) or is plainly a step in a criminal plan (as [an] account of bank seeurity [to be used in furtherance of a bank robbery] would be if the author were not also writing an article on bank security for some journal).

Id. at 778; see also Matsuda, supra note 2, at 2351 ("Conspiratorial speech, inciting speech, fraudulent speeeh, obscene speech, and defamatory speech are examples of words that seem to emerge from human mouths as more than ideas," implying that they are part of the "few limited categories of speech that take on qualities beyond expression" and may therefore be regulated.); Comment, Coercion, Blackmail, and the Limits of Protected Speech, 131 U. PA. L. REV. 1469, 1471 (1983) (coinparing "coercive" speech such as threats of violence to direct violent acts).

49. Delgado, supra note 16, at 146-47 (einotional distress suffered by victim of racial invective is sufficient to justify tort award); Lasson, Racial Defamation and Free Speech: Abusing the First Amendment, 17 Colum. Hum. RTS. L. REv. 11, 46-47 (1985) (racially defamatory speech is a form of assault lying outside the proteetion of the first amendment, and its victims are entitled to proteetion); see also Collin v. Smith, 578 F.2d 1197, 1206 (7th Cir.) (acknowledging unredressed mental and emotional harm to residents resulting from Nazi march through the largely Jewish Village of Skokie, Illinois), cert. denied, 439 U.S. 916 (1978).

Using Professor Greenawalt's framework, one might classify the assaultive aspects of epithets as "situation altering" and therefore beyond the pale of protected expression. See supra note 48.

50. 379 U.S. 536 (1965).

51. L. TRibe, American Constitutional LAw § 12-10, at 856 (2d ed. 1988) ("The first amendment need not sanctify the deliberate infiction of pain simply because the vehiclc used is verbal or symbolic rather than physical.").

52. 315 U.S. 568 (1942). 
fascist."53 According to later decisions of the Court, fighting words lack protection because they do not contribute to truth-seeking and are therefore not part of the marketplace of ideas. ${ }^{54}$ They do not express opinion but are solely emotive. ${ }^{55}$

If the Court had believed the situation in Chaplinsky could have been remedied by discussion of the falsehood and fallacies of the speaker's proposition, it would not have upheld Chaplinsky's conviction. ${ }^{56}$ If there had been tinie "to expose through discussion the falsehood and fallacies, to avert the evil by the process of education, the remedy to be applied" would have been "more speech, not enforced silence." 57 Thus, the Chaplinsky decision represents the Court's underlying recognition that some upsetting words, when personally directed to a particular target, may be punished legitimately by the state.

Therefore, more speech cannot readily eliminate the pressure for the target of a group-based epithet to escape and avoid the university environnent or her reinforced belief that she does not belong at the umiversity. Once the target has been jostled, the damage is done. She may be upset for the next hour, the next week, or for her entire lifetinie as a result of repeated incidents.

Must she be forced constantly to respond with analytical argument to each verbal assault? The answer is plainly "no" for two reasons. First, as argued below, she has a right to be left alone from directly assaultive confrontations, even in public. ${ }^{58}$ Second, she cannot possibly respond within the marketplace of ideas to a communication that is essentially and priniarily assaultive and therefore outside the realm of

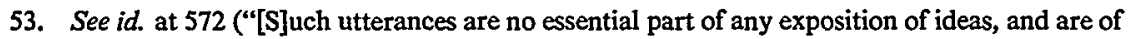
such slight social value as a step to truth that any benefit that may be derived from them is clearly outweighed by the social interest in order and morality.").

54. See, e.g., Hustler Magazine, Inc. v. Falwell, 485 U.S. 46, 56 (1988) ("not all speech is of equal First Amendment importance") (quoting Dun \& Bradstreet, Inc. v. Greenmoss Builders, Inc., 472 U.S. 749, 758 (1985)); id. at 56 (citing Chaplinsky, 315 U.S. at 571-72).

55. See Smolla, supra note 3, at 182-86 "When emotional speech stands naked and alone, however, with no plausible content to clothe it, the first amendment values requiring a 'free trade in ideas' do not apply.") (emphasis in original).

56. Under current first amendment doctrine, the Court would almost certainly be wrong to uphold a conviction on the particular facts of Chaplinsky. The holding is inconsistent with New York Times Co. v. Sullivan, 376 U.S. 254, 270, 279-83 (1964), which allowed wide latitude for criticism of public officials.

57. Whitney v. California, 274 U.S. 357, 377 (1927) (Brandeis and Holmes, JJ., concurring), overruled, Brandenburg v. Ohio, 395 U.S. 444, $448-49$ (1969). The paradigmatic situation where listeners have iusufficient opportunity to respond "rationally and deliberately" to speech (as marketplace theory contemplates) is "[t]he often cited example of someone shouting 'Fire' in a crowded theater." Greenawalt, supra note 48 , at 678 . To the extent that listeners can respond in a rational way, the justification for repressing the speaker is weakened "if active response is likely to precede deliberation." Id. at 679 .

58. See infra Section II(B). 
ideas. Rational argument will not remedy the intimidation and fear visited upon the target of a group-based epithet.

\section{The First Amendment Does Not Require That the Victim's Interest Be Ignored}

The first amendment does not require that a court coinpletely discount a targeted hearer's liberty interests in order to protect freedom of expression appropriately. ${ }^{59}$ "To enforce freedom of speech in disregard of others would be harsh and arbitrary in itself."60 A Kansas court enunciated precisely tlis idea when, discussing a five-to-fifteen-minute racist tirade, it wrote:

$[T]$ his vituperation was well beyond the bounds of freedom to blow off harmless steam. It is not a burden of American citizenship in the State of Kansas that such vitriohic bullying as was turned by [defendant] against [plaintiff], and its emotional and physical consequences, must be accepted without possibility of redress and accepted as often as it amuses the speaker. ${ }^{61}$

Thus, the court must be able to find some accommodation between the competing interests of speaker and targeted hearer.

The line of cases beginning with New York Times Co. v. Sullivan, ${ }^{62}$ in which the Supreme Court decided the degree to which the first amendment restricts enforcement of state hibel laws, offers an example of one such attempt at accommodation between speaker and hearer. Public figures must ineet a higher standard of proof in order to recover for libel. ${ }^{63}$ The New York Times rule is based in part on the fact that public figures have greater access to the market. ${ }^{64}$ Mass media are more likely to report public figures' views and grievances about a false portrayal. ${ }^{65}$ Moreover, public figures willingly subject theinselves to heightened public attention and scrutiny, and thus waive solne degree of protection from

59. See, e.g., Rowan v. United States Post Office, 397 U.S. 728, 736 (1970) ("the right of every person 'to be let alone' must be placed in the scales with the right of others to communicate"); Curtis Publishing Co. v. Butts, 388 U.S. 130, 147 (1967) (plurality opinion) (accommodation is necessary between harms of defamation and protection of speech); Collin v. Smith, 578 F.2d 1197, 1206 (7th Cir.) (denying city power to prevent Nazi march, court nonetheless recognized "[i]t would be grossly insensitive to deny, as we do not, that the proposed demonstration would seriously disturb, emotionally and inentally, at least some, and probably many of the Village's residents"), cert. denied, 439 U.S. 916 (1978); Matsuda, supra note 2, at 2376 ("The application of absolutist free speech principles . . . is a choice to burden one group with a disproportionate share of the costs" of free speech.).

60. Kovacs v. Cooper, 336 U.S. 77, 88 (1949) (upholding constitutionality of ordinance prohibiting use of sound trucks on public streets).

61. Gomez v. Hug, 7 Kan. App. 2d 603, 610, 645 P.2d 916, 922 (1982)

62. 376 U.S. 254 (1964).

63. Id. at $279-83$.

64. See Gertz v. Robert Welch, Inc., 418 U.S. 323, 344 (1974).

65. Id. 
damage to reputation. ${ }^{66}$ Thus, since public figures have more access to the market, first amendment concerns justify "exact[ing] a ... high price froin the victims of defamatory falsehood."

By contrast, private figures are required to satisfy a lower constitutional standard to recover damages because their relative lack of access to the media lessens the efficacy of their remedy in the marketplace of ideas. ${ }^{68}$ Tlus, the Court has recognized that a speaker has a greater interest in speaking about a public figure and, as a result, that the public figure's protectable reputation interest is more narrow than that of a private figure. The Court balanced not only the speaker's interest in speaking, but the quantuin of the harm done to the defamed person. The Court's analysis properly considered the interest of a person liarmed by speech when determining whether particular speecli can be punished within the strictures of the first ainendinent.

\section{Current Doctrine as Applied Does Not Address the Harms Caused by Assaultive Epithets}

\section{a. Chaplinsky's Logical and Precedential Value Is Questionable}

Althougli Chaplinsky recognized that certain kinds of speech are not remediable through the inarketplace of ideas, its status as precedent is questionable. The Court frequently cites Chaplinsky in dicta, ${ }^{69}$ but it has also hinted that it might overrule the decision were it presented with an appropriate case. ${ }^{70}$ In addition, its doctrinal formulation has several flaws that make it undesirable as a foundation case on which to build a doctrine to justify restrictions on group-based epithets. The first problein

66. Id. at 342 .

67. Id.; see also Post, The Social Foundations of Defamation Law: Reputation and the Constitution, 74 CALIF. L. REv. 691, 722 (1980) ("The Court viewed these values as so pressing and important that it did not pause to consider the nature of competing interests in the protection of private reputation."); id. at 727 (quoting Harlan, J., dissenting in Rosenbloom v. Metronedia, Inc., 403 U.S. 29 (1971)) (harm done by defamation is similar to a "taking" of property).

68. Gertz, 418 U.S. at 344-45.

69. See, e.g., United States v. Eichınan, 110 S. Ct. 2404, 2407 (1990) ("fighting words," like obscenity, do "not enjoy the full protection of the First Amendment"); id. (citing Chaplinsky, 315 U.S., at 572); Hustler Magazine, Inc. v. Falwell, 485 U.S. 46, 56 (1988) (citing Chaplinsky); Garrison v. Louisiana, 379 U.S. 64, 70 (1964) (citing with approval statutes in both Chaplinsky and Beauharnais as examples of limiting speech restriction to that "behavior which exceptionally disturbs the conmunity's sense of security") (quoting MODEL PENAL CODE $§ 250.7$ comments, at 44 (Tent. Draft No. 13, 1961)).

70. See Eichman, 110 S. Ct. at 2410 (dicta) (implying that epithet-based restriction may not survive scrutiny).

Beauharnais v. Illinois, 343 U.S. 250, 252 (1952), in which the Court upheld a group libel law prohibiting speech exposing African American citizens to "contenpt, derision or obloquy," is similarly in contradiction to the bulk of first amendinent law. Because Beauharnais' couception of harmful speech is so broad as to reach odious ideas about a societal class of people rather than protecting only harms to specific persons, it is inconsistent with New York Times and its progeny. See infra text accompanying notes 238-50 (discussing Beauharnais in detail). 
witl Chaplinsky is the Court's use of the likelihood of violent response by the target as a divining rod of access to a market remedy, since it reflects the use of inappropriate and now-outdated social values. ${ }^{71}$ The "fighting words" doctrine recognizes and validates only stereotypically male responses to assaultive behavior. ${ }^{72}$ It assumes that violence is, under some circumstances, the appropriate and "reasonable" response to speech. It also assumes that the only harms that "count" are those that "ordinary men know are likely to cause a figlit."73 Conversely, it allows a lieckler's veto to be given effect wlienever ordinary (not rational or reasonable) men would respond to particular speecl with violence. For example, one court employed Chaplinsky to uphold a statutory ban on lomosexual solicitations on the ground that the ordinary response to a homosexual solicitation (but not a lieterosexual one) would be violence. ${ }^{74}$

Chaplinsky's underlying acceptance of violence as a reasonable response to speecl,, lowever, forgets the fundamental social contract notion that, in modern society, eacli person has yielded to the state the right to use violence to self-enforce lier rights. ${ }^{75}$ The citizen therefore entitles the state to use force on lier belialf to redress wrongs done to her. ${ }^{76}$ Society's interest $\mathrm{m}$ maintaining tlie public peace is thereby served.

Another problem with Chaplinsky's "fighting words" doctrine is that it implicitly involves the sort of government ranking of speech prohibited by the first amendment. ${ }^{77}$ As one commentator wrote, "Chaplinsky is foolishly simplistic . . . in maintaming that emotive speecli is no part of the family of protected [speech]. . . . Chaplinsky also is flawed because it is not anything like our current first amendment skepticism concernimg the ability of decisionmakers to separate the various strands of speech."78

Chaplinsky is "foolislily simplistic" because it rests upon the notion that some categories of words are outside the scope of the first amendment and are therefore not protected. ${ }^{79}$ Such per se rules about speech

71. See Comment, Sticks and Stones: Homosexual Solicitations and the Fighting Words Doctrine, 41 OHı ST. L.J. 553, 560-62 (1980) (authored by S. Adele Shank) (fighting words doctrine assumes "unavoidable relationship" between certain words and violent reactions).

72. Matsuda, supra note 2, at 2355.

73. Chaplinsky, 315 U.S. at 573.

74. State v. Phipps, 58 Ohio St. 2d 271, 277-78, 389 N.E.2d 1128, 1133 (1979); see also Comment, supra note 71, at 553, 561-62, 571-74 (Phipps shows danger that fighting words doctrine may legitimize otherwise impermissible statutes); infra Section III(C) (discussing Phipps).

75. See R. EPSTEIN, supra note 1, at 111; Pilon, Property Rights, Takings, and a Free Society, 6 HARV. J.L. \& PUB. POL'Y 165, 185-86 (1983).

76. R. EPSTEIN, supra note 1, at 111; Pilon, supra note 75, at 186.

77. See Comment, supra note 71 , at 560-62.

78. Smolla, supra note 3, at 198-99 n.103 (emphasis in original).

79. Chaplinsky, 315 U.S. at 571-72 ("[1]t is well understood that the right of free speech is not absolute at all times and under all circumstances. There are certain well-defined and narrowly 
are antithetical to first amendment jurisprudence, which requires that actual harm in a particular context be shown in order to sanction speech. $^{80}$

\section{b. Chaplinsky Does Not Provide Protection Because Courts Have Consistently Underestimated the Harms of Group-Based Verbal Abuse}

Chaplinsky's analytical structure requires a court to determine whether the speaker's words are such that the "ordinary man" would be incited to violence. The problem with this formulation is that the government and courts-actmg in an abstract "reasonable person" vacuum-tend to underestimate the harms done to members of societally disfavored groups by assaultive speech. Because group-based verbal abuse has long been acceptable and accepted silently by the victim, ${ }^{81}$ such abuse causes the " 'kind of hurt that liappens on a level that can't even produce tears, because it's much farther down than that." "82 "[R]acist speech is so common that it is seen as part of the ordinary jostling and conflict people are expected to tolerate, rather than as fight-

limited classes of speech, the prevention and punishment of which have never been thought to raise any Constitutional problem. These include the lewd and obscene, the profane, the libelous, and the insulting or fighting words ....") (footnote omitted).

80. See New York Tines Co. v. Sullivan, 376 U.S. 254, 283 (1964) (action for defamation by public figure requires proof of falsification and clear and convincing proof of actual malice).

81. See, e.g., Contreras v. Crown-Zellerbach Corp., 88 Wash. 2d 735, 741, 565 P.2d 1173, 1177 (1977) (racial epithets "once part of common usage").

Silence as a response by women and people of color to speech they find offensive or degrading was denionstrated here at Boalt Hall, home of the California Law Review. At the end of each Fall semester, second- and third- year students present an "Am. Jur. Show" for first-year students. The show consists of skits parodying law school and law professors. Each year, some skits contain jokes that women and people of color find hurtful and insulting. For example, in last year's show, one skit portrayed a conference of the Supreme Court. In the skit, Justice O'Connor paid more attention to firting with her colleagues than participating in the legal discussion. According to the dismayed coordinator of the show, the skit characterized Justice O'Connor as being "there to serve the sexual needs of the nien on the Court." Murthy, Freedom to Express vs. Freedom to Offend, Boalt Hall Cross-Examiner, Apr. 5, 1991, at 3 (quoting Kirsten Downs). In the same skit, Justice Marshall, seated in a wheelchair, had a basketball bounced off his head by another Justice. His only words in the lengthy skit were "I am a pretty flower" in response to a legal question posed by one of his colleagues.

In the 1989 show, a female Boalt professor's pregnancy was graphically and crudely parodied. The professor was portrayed "breaking water in the class room and being carried off in labor loudly noaning." Id. One of the coordinators of last year's show discussed the reaction of students to the material they found offensive: "A general silence, shock, hissing. Someone pointed out to me that the white students tended to hiss, while the students of color were just silent, shocked." Id. (emphasis added).

82. Love, Discriminatory Speech and the Tort of Intentional Infliction of Emotional Distress, 47 WASH. \& LeE L. REv. 123, 158 n.277 (1990) (quoting Carter, Black Americans Hold a TV Mirror Up to Their Life, N.Y. Tiunes, Aug. 27, 1989, § 2, at 1, col. 4). 
ing words." 83 The abuse falls outside the fighting words category ${ }^{84}$ because the courts expect the "reasonable man" to tolerate such abuse as "ordinary jostling." 85 But one reason the abuse is so coininon is precisely because the courts do not sanction it. Thus, victims of epithets are trapped in a judicially created vicious circle: epithets are ubiquitous so "reasonable" people are expected to tolerate them; but epithets are ubiquitous in part because courts do not sanction those who direct them at others. 86

Logan v. Sears, Roebuck \& Co. ${ }^{87}$ illustrates the tendency of courts to underestimate these "invisible" harms. ${ }^{88}$ In Logan, a department store einployee referred to the plaintiff over the telephone as "queer as a threedollar bill."89 Denying recovery, the court wrote:

We are unwilling to say that the use of the word "queer" to describe a homosexual is atrocious and intolerable in civilized society. We recognize that there are other words favored by the homosexual community in describing themselves, but the word "queer" has been used for a long time by those outside that community. ${ }^{90}$

Thus, the Logan plaintiff and others similarly situated are simply expected to accede to the dehumanizing speech of others inerely because the practice is long standing.

The court in Logan was not alone in ignoring the harms of a longstanding social practice in order to justify a legal result. The Supreme

83. Matsuda, supra note 2, at 2355.

84. Id. at 2356.

85. See Love, supra note 82, at 158 (victims of such epithets arc expected to be "tough people" who do not suffer severe emotional distress from group-based epithets).

86. Similarly, some have argued that the very enactment of university regulations that protect minority groups undermines any argument based upon the powerlessness of such groups and the systemic problems of exclusion and discrimination they face. See Comment, A Libertarian Critique of University Restrictions of Offensive Speech, 79 CALIF. L. REv. 825, 880 (1991) (authored by David F. McGowan and Ragesh $\mathrm{K}$. Tangri). In other words, legislation protecting powerless groups could never be justified on those grounds because the very enactment of the legislation would render the protected group "powerful."

But such a result would be the ultimate irony: the powerless would be denied legal protection from societal discrimination and harassment because of their "power" in achieving some modicum of legal protection. Among other problems, this line of argument overstates the power of legal restrictions to effectuate social change. Even if minorities have obtained some political power, no one can seriously dispute that societal discrimination and stereotypes persist in spite of legal restrictions.

87. 466 So. 2d 121 (Ala. 1985).

88. Compare Collin v. Smith, 578 F.2d 1197, 1210 (7th Cir.) (Wood, J., concurring) ("It may also be well to remember that often 'words die away, and flow off like water-leaving no taste, no color, no smell, not a trace.' "), cert. denied, 439 U.S. 916 (1978) with id. at 1206 (majority opinion) (acknowledging unredressed mental and emotional harm of Jewish residents).

89. Logan, 466 So. $2 \mathrm{~d}$ at 122.

90. Id. at 123-24 (emphasis added). 
Court also employed this line of reasoning in Bowers v. Hardwick, ${ }^{91}$ where it upheld a state sodomy law as applied only to gay men. The Court's reasoming in Bowers, according to Professor Tribe, "inverts the equal protection axiom of heightened judicial sohitude for despised groups and their characteristic activities and uses that inverted principle to bootstrap antipatlyy toward hoinosexuality into a tautological rationale for continuing to criminalize lomosexuality."92 The long-standing practice of defaming and humiliating individuals based upon their affiliation with a societally unpopular status has not only caused its victims to internalize and accept the abuse, but has also caused courts-at best-to fail to recognize the harms of group-based epithets because those harms are so pervasive in daily life that they do not stand out. At worst, courts have theinselves adopted and endorsed opprobrium toward societally disadvantaged groups and used that opprobrium as a justification for denying any redress.

\section{The Precedents and the Prospects for Remedying Such Harms}

The Court lias at times recognized the notion that personally abusive speecl can be legitimately restricted in soine circumstances; unfortunately, that recognition has only coine in cases that are flawed for other reasons. Although Beauharnais v. Illinois ${ }^{93}$ did correctly recognize that the first ainendinent does not protect a liarmful act inerely because the speaker accomplishes it througli words, ${ }^{94}$ enforceinent of group libel coines too close to the core protections of the first amendment for the courts to recognize it safely. ${ }^{95}$ Similarly, despite Chaplinsky's misguided reliance on violence as the diviming rod of market access and the fighting words doctrine's corresponding inability to recognize liarns done to systematically intimidated minority groups, it too evinces the same unstated core of truth as Beauharnais: speech used as a tool to harm individuals presents a special problein. ${ }^{96}$

To this point, the discussion of the harms of group-based verbal

91. 478 U.S. 186, 192 (1986) (upholding state's proscription against consensual acts of sodomy on the ground that animus against gay men has "ancient roots").

92. L. TRIBE, supra note $51, \S 15-21$, at 1428 .

93. 343 U.S. 250 (1952).

94. Id. at 255-57; see also id. at 258 ("if an utterance directed at an individual may be the object of criminal sanctions, we cannot deny to a State power to punish the same utterance directed at a defined group").

95. See supra note 70 and accompanying text; infra notes $238-50$ and accompanying text.

96. See Chaplinsky, 315 U.S. at $571-72$ (such speech outside the marketplace of ideas). Chaplinsky's error was in considering the harm done by a particular instance of assaultive speech as capable of measurement by the likelihood of a violent response by the target. Chaplinsky, 315 U.S. at $\mathbf{5 7 3}$ (words that arouse ordinary men to blows are punishable). It ignored harms that are just as severe, but that are expressed through intimidated silence and escape and avoidance. See supra text accompanying notes $83-92$. 
abuse has been limited to the harm inflicted upon the target. The argument is therefore subject to the criticism that, although an anti-slur regulation may protect the victim, the speech restriction may nonetheless harm society by restricting free exchange of ideas and self-expression. In Garrison v. Louisiana, ${ }^{97}$ the Court discussed this issue in the defamation context, tracing the historical threads of the social contract notion. ${ }^{98}$ Reviewing the crimmal defamation conviction of a district attorney for criticizing local criminal court judges in a press statement, the Court alluded to the basic principle that individuals have ceded to the state their right to use violence to redress wrongs committed against them. ${ }^{99}$ The Court characterized the development of defamation law as trading "chivalrous satisfaction for damages." 100 Criminal defamation fell into disuse because "under modern conditions, when the rule of law is generally accepted as a substitute for private physical measures, it can hardly be urged that the maintenance of peace requires a criminal prosecution for private defamation."101

The Court in Garrison implied that the type of verbal abuse at issue is disruptive not only to the targeted hearer but to society in general. The Court characterized criminal prosecutions for defamation as inappropriate except where speech "exceptionally disturbs the community's sense of security." 102 The Court then cited both Chaplinsky v. New Hampshire ${ }^{103}$ and Beauharnais v. Illinois ${ }^{104}$ as examples of just such socially disruptive speech. ${ }^{105}$ That the Court singled out Chaplinsky and Beauharnais indicated its recognition that personally directed attacks are disruptive to society as well as to the targeted individual. ${ }^{106}$ Although society's mterest in maintaining the public peace may often be too undifferentiated to justify punishment, the fact that a particular assaultive speaker's words are socially disruptive implies that society will not be harmed by restricting her speech. ${ }^{107}$

The validity and scope of both cases-particularly Chaplinsky,

97. 379 U.S. 64 (1964).

98. Id. at 69.

99. Id.; see supra notes $75-76$ and accompanying text.

100. Id.

101. Id. at 69 (quoting Emerson, Toward a General Theory of the First Amendment, 72 YALE L.J. 877, 924 (1963)).

102. Id. at 70 (quoting Model PenAl Code, Tent. Draft No. 13, § 250.7 comment, at 44 (1961)).

103. 315 U.S. 568 (1942).

104. 343 U.S. 250 (1952).

105. Garrison, 379 U.S. at 70.

106. Id. (personally directed insulting speech tends to cause breaches of the peace and lead to public disorder).

107. Cf. Lasson, Group Libel Versus Free Speech: When Big Brother Shouid Butt In, 23 DUQ. L. REv. 77, 114-16 (1984) (evils of racist expressive behaviors are "a substantive evil not only to those persons directly targeted, but to all society"). 
which emphasizes face-to-face confrontations-have therefore become issues of renewed importance in light of the enactment of the university regulations. Many state universities, and the University of California in particular, have retied upon the core of truth within Beauharnais and Chaplinsky in formulating their anti-slur regulations. ${ }^{108}$ The conflicting signals the Court has sent regarding the present vitality of Chaplinsky ${ }^{109}$ probably emboldened the drafters of the regulations.

Even if neither Chaplinsky nor Beauharnais is exphicitly overruled, one should not attempt to justify state university anti-slur regulations on the authority of those decisions because of their doctrinal and theoretical weaknesses. One can and should justify the regulations on the basis of a theory that takes into account the harm done to the targeted individual as well as the free speech interests of speaker and society. To develop that justification, this Coniment must first examine the types of speech harms which can be pumished under present first amendment doctrine.

II

The State Interest in Protecting a Victimized Hearer From Unwanted, Harassing SPEech

In order for a state university to punish a student for directing assaultive group-based epithets at another individual, it must articulate a state interest of sufficient importance to justify infringement of the speaker's free speech interest. ${ }^{110}$ This Part will first examine the importance of defining the state's interest in a first aniendnient case. It then suggests a content-neutral state interest in enforcing a personal "civility zone" which allows imdividuals to exclude specifically targeted, unwanted speech from their immediate persons. To define the bounds of that civility zone, the Part concludes by examining the tort of intentional infliction of emotional distress.

\section{A. The Centrality of the State Interest in First Amendment Jurisprudence}

The characterization of the state's interest in enforcing a university epithet restriction is the crucial step to determining its constitutional validity. The first amendment plainly forbids the censorious imposition of a state orthodoxy. ${ }^{111}$ If the state university restrictions are cast in that

108. See supra note 23 and accompanying text.

109. See supra text accompanying notes $69-70$.

110. See Nimmer, The Meaning of Symbolic Speech Under the First Amendment, 21 UCLA L. REv. 29, 44-45, 45 n.63, $61-62$ (1973) (focusing on state interest to clarify conduct/speech distinction).

111. See New York Times Co. v. Sullivan, 376 U.S. 254, $273-77$ (1964) (dicta) (Sedition Act of 1798 inconsistent with first amendment). 
liglit, they are clearly unconstitutional. Indeed, Justice Brennan, writing for the Court in United States v. Eichman, ${ }^{112}$ inplied such a view:

We are aware that desecration of the flag is deeply offensive to many. But the same might be said, for example, of virulent ethnic and religious epithets. . . . "If there is a bedrock principle underlying the First Amendment, it is that the Government may not prohibit the expression of an idea simply because society finds the idea itself offensive or disagreeable."113

It is not surprising, then, that few supporters of university anti-slur regulations care to cast the policies as enforcing a value judgment or restricting the expression of odious opinions. Professor Matsuda, however, did just that: "We can attack racist speech-not because it isn't really speech, not because it falls within a hoped-for neutral exception, but because it is wrong." 114 Professor Matsuda's justification for restrictions on racist speecl is facially inconsistent with traditional first annendinent jurisprudence, which views as legitimate only tlose state interests not based upon the substantive content of commurrication. ${ }^{115}$ In essence, Professor Matsuda's unconventional argunnent justifies a speecli restriction on the basis of a need for a collective value judgment against societally destructive speech. ${ }^{116}$

Anotlier possible justification for upholding a state university antislur regulation is the argument that the conduct it prohibits is "not speecl1" even thougl the "conduct" consists of spoken words. ${ }^{117}$ This reasoning, lowever, relies upon a tautology because to argue tliat epithets are not speecli or not communication is to force a strained definition upon those simple terms. The Supreme Court rejected formalistic limitations on speecli when it recogmized that syınbolic coinmunication is subject to first amendinent protection. ${ }^{118}$ Epitliets, figliting words, and

112. 110 S. Ct. 2404 (1990) (finding unconstitutional statute prohibiting desecration of the American flag).

113. Id. at 2410 (quoting Texas v. Johnson, 491 U.S. 397, 414 (1989)).

114. Matsuda, supra note 2, at 2380 (emphasis added); see also Note, Group Vilification Reconsidered, 89 YALE L.J. 308, 332 (1979) (arguing that "group vilification" can be prohibited because, as a false statement of fact, it "trades not in ideas but in pernicious and undeliberated passions" and, consequently, is not remediable by the market).

115. L. TR1BE, supra note $51, \S 12-2$, at 790 ("Any adverse government action aimed at commumicative impact is presunptively at odds with the first amendinent.").

116. See Matsuda, supra note 2, at 2379 ("In a society that expresses its moral judgments through the law, and in which the rule of law and the use of law are characteristic responses to many social phenomena, this absence of laws against racist speech is telling."); see also Kretzmer, Freedom of Speech and Racism, 8 CARDOzo L. REV. 445, 513 (1987) (restriction on racial speech may "have value as a strong moral statement of social solidarity and as a rejection of racisin just when such a stateinent is most needed").

117. See Nimmer, supra note 110 , at $35-38$ (discussing in detail this justification).

118. See, e.g., United States v. Eichman, 110 S. Ct. 2404, 2407 (1990) (flag burning); Texas v. Johnson, 491 U.S. 397, 410 (1989) (same); Tinker v. Des Moines Ind. Community School Dist., 393 U.S. 503, 505 (1969) (wearing of black arm bands by high school students to protest Vietnam War 
other offensive insults do communicate. If they did not have some coininunicative effect on the hearer, then the hearer would neither understand nor care about hearing thein.

The notion that offensive or assaulting speech is not speech is disingenuous and overly simphistic, just as is the notion that "libel is not speech"119 and therefore not protected by the first amendment. If a libelous stateinent did not communicate soinething (falsely), then it would not be libelous. Such arguments confuse expression with the availability of a nuarket remedy through more speech. The reason that both hibel and personally directed epithets cannot often be remedied within the niarketplace of ideas is not that the speaker has not communicated or expressed soinething, but rather that the speaker's expression has done some injury to tlie targeted hearer. To the extent that the hearer has no marketplace reinedy, the first amendment should not prohibit the state from providing a legal remedy through punishinent of the speaker or money damages.

The analytical framework that classifies certain utterances or expressive behaviors as nonspeech inakes it far too easy to chip away at the fundamental principles of the first amendment. The hidden balancing necessary for such an approach will lead to unpredictable results. ${ }^{120}$ If the Court is going to engage in a balancing process to decide which speech the state inay properly regulate, it ought to do its balancing and reasoning in the open. A judicial process with such openness focuses on the state's interest justifying a restriction on speech rather than on a ranking of the social worth of the speech itself.

Thus, the appropriate doctrinal route to justifying a university antislur speech restriction requires the articulation of a content-neutral state interest. $^{121}$ For example, one of tlie earliest state interests the Court recognized as valid was the prevention of inciteinent to violence. ${ }^{122}$ The first aniendinent "clear and present danger"123 test embodies the state's interest in protecting itself and its citizenry froin imminent harm. The interest is enforceable by limiting speech where the government can

constituted speech). But see United States v. O'Brien, 391 U.S. 367, 376-82 (1968) (government's interest in efficiently raising armies was conteut-neutral justification for punishment of defendant for burning draft card). For an overview, see Nimmer, supra note 110, at 33, 35-38 (recognizing potential for vast oversiniplification in analyses employing speech versus nonspeech dichotoiny).

119. E.g., Lasson, supra note 49 , at 34 .

120. Pilon, supra note 75 , at 182 (criticizing judicial process utilizing implicit balancing of interests while exphicitly stating other grounds for decision).

121. See L. TRIBE, supra note $51, \S 12-2$, at $791-94$ (content-neutral track of analysis nore amenable to justifying a speech restriction than content-dependent justification).

122. Id. $\S 12-9$, at 841 (citing Schenck v. United States, 249 U.S. 47 (1919)).

123. E.g., Schenck, 249 U.S. at 52 (words that would ordinarily be within protection of first aniendment are subject to prohibition if they "create a clear and present danger" of an evil which Congress has power to prevent). 
prove that the speaker realistically threatens a violent overthrow of the government $^{124}$ or imminent violence. ${ }^{125}$

The state inust carefully delineate its interest in protecting against imminent violence, however, in order to protect a speaker addressing a hostile audience. ${ }^{126}$ Otherwise, the state can enforce a "heckler's veto" by allowing hostile histeners to silence the speaker. ${ }^{127}$ Unless carefully delimited, enforcelnent of this state interest risks prohibiting not only speecl with which the state disagrees but also speech with which the public at large disagrees. Examining the particular context of speech instead of ranking and classifying particular words can help prevent such a result.

The fighting words doctrine of Chaplinsky v. New Hampshire ${ }^{128}$ provides an example of the dangers of grounding analysis in ranking speecli ratlier than in examining the state's justification for infringing upon tlie speaker's free speech interest. In Chaplinsky, the Court's constitutional inquiry came to a resounding lialt when it found that Chaplinsky's words were "no essential part of any exposition of ideas, and [were] of sucli sliglit social value as a step to trutli that any benefit that may be derived froin them is clearly outweighed by tlie social interest in order and morality." 129 The Court therefore never seriously examined the state's justification for punishing Chaplinsky. It failed to consider that

124. See Dennis v. United States, 341 U.S. 494, 496, 501 (1951) (upholding Smith Act, which prohibits conspiracies to teach or advocate overthrow of government).

125. E.g., Feiner v. New York, 340 U.S. 315, 321 (1951) ("the police cannot be used as an instrument for the suppression of unpopular views" but they are not powerless when "the speaker passes the bounds of argument or persuasion and undertakes incitement to riot").

126. E.g., Collin v. Smith, 578 F.2d 1197, 1206 (7th Cir.) ("The problem with engrafting an exception on the First Amendment for such situations is that they are indistinguishable in principle from speech that invite[s] dispute, .... induces a condition of unrest, creates dissatisfaction with conditions as they are, or even stirs people to anger.' ") (quoting Terminiello v. City of Chicago, 337 U.S. 1, 4 (1949)) (omissions in original), cert. denied, 439 U.S. 916 (1978).

127. In Glasson v. City of Louisville, 518 F.2d 899, 901-02 (6th Cir.), cert. denied, 423 U.S. 930 (1975), a woman stood alongside the route of President Nixon's motorcade holding a sign allegedly reading, "Murderer, teach us to hate and kill poverty, disease and ignorance, not each other." Two police officers destroyed her sign on the grounds that it was "inflammatory" and that hecklers threatened to distnrb the peace. Id. at 902 . The court noted that the officers made no attempt to calm down the hecklers or to protect the woman; moreover, the officers testified that had a sign supportive of the President caused a ruckus they would have protected the speaker unless trouble had started. Id. The court rejected the notion that the plaintiff had "somehow forfeited the protection afforded her message by the Constitution because it unintentionally evoked a hostile reaction from others." Id. at 905 . Compare Feiner, 340 U.S. at 317 (where speaker endeavored to arouse blacks to rise up in arms against whites, in a "loud, high pitched voice" before a mixed audience, state interest in maintaining peace justified speaker's arrest after a warning) with Cohen v. California, 403 U.S. 15, 21 (1971) ("Any broader view of this authority [to prevent breach of the peace] would effectively einpower a majority to silence dissidents simply as a matter of personal predileetions.") and Terminiello v. City of Chicago, 337 U.S. 1, 3 (1949) (speaker critical of "various political and racial groups" could not be punished for breach of the peace).

128. 315 U.S. 568 (1942).

129. Id. at 572 . 
the state's interest in inaintaining the public order was rather weak since the police officer who was supposedly incited to violence was an agent of the state itself. ${ }^{130}$ Instead of evaluating what interest the state might lave in prohibiting face-to-face, personally abusive speech, the Court invented a conclusory concept (figliting words), which seemingly fit neatly into the paradigmatic mold of preventing violence.

This analytical shortcut undoubtedly explains why the Court in Eichman could in one breath inply that restrictions on racial epithets are plainly unconstitutional while casually citing Chaplinsky with approval. ${ }^{131}$ Thus, while there is substantial confusion as to the status of the fighting words exception articulated by Chaplinsky, ${ }^{132}$ a broader lesson remains to be learned from that case and its curious longevity: The Court's cliaracterization of the state interest is the key to the validity of a regulation or statute under the first amendment. ${ }^{133}$ The next Section therefore seeks to define a permissible state interest to justify pumishment of a state university student for directing group-based epithets against persons on the umiversity campus.

\section{B. The Civility Zone}

The Supreine Court, as part of the captive audience doctrine, has long recognized that states have an interest in protecting individuals froln some speecl they do not wish to hear. ${ }^{134}$ States can prohibit colnmunication-substantively offensive or not-when it is inflicted upon people in their looines or in such a way that they cannot avoid it. ${ }^{135}$ In this Section, I will argue that the captive audience doctrine provides the foundation for protection of a personal "civility zone," which would allow individuals to refuse unwanted conmunication even in public foruins. ${ }^{136}$

130. See New York Times, 376 U.S. at 270 (stating that "debate on public issues should be uuinhibited, robust, and wide-open, and that it may well include vehement, caustic, and sometimes unpleasantly sharp attacks on government and public officials").

131. Eichman, 110 S. Ct. at 2407,2410 (dicta).

132. See supra notes $69-70$ and accompanying text.

133. See, e.g., City of Renton v. Playtime Theatres, 475 U.S. 41,47 (1986) (state may regulate secondary effects of speech); Heffron v. International Soc'y for Krishna Consciousness, 452 U.S. 640, 647-48 (1981) (state may enforce content-neutral time, place, and manner restrictions); United States v. O'Brien, 391 U.S. 367, 376 (1968) (state interest unrelated to suppression of ideas will justify a statute that has an impact on speech).

134. Rowan v. Uuited States Post Office, 397 U.S. 728, 737 (1970) ("Nothing in the Constitution compels us to listen to or view any unwanted communication, whatever its merit."); Kovacs v. Cooper, 336 U.S. 77, 79-81 (1949) (upholding municipal ordinance prohibiting "loud and raucous" sound trncks on city strects).

135. See generally L. TRIBE, supra note 51, § 12-19, at 948-49, 949 n.24 (discussing captive audience doctrine).

136. The genesis of the notion of a civility zone is found in Professor Arkes' argument that society has an interest in a general code of civility. See Arkes, Civility and the Restriction of Speech: 
The captive audience doctrine recognizes that hearers in enclosed spaces have an interest in not having speech forced upon them. The state may regulate speech when the "degree of captivity makes it impractical for the unwilling viewer or auditor to avoid exposure."137 The degree of captivity is fact-bound. At the noncaptive end of the spectrum are Cohen's "Fuck the Draft" jacket in a courthouse hallway ${ }^{138}$ and Jacksonville's ban of nudity on drive-in movie screens. ${ }^{139}$ In both those cases, the courts expected unwilling viewers to avert their eyes if they found the communication offensive.

At the captive end of the spectruin are environments such as a pubhe streetcar: ${ }^{140}$ "One who hears disquietimg or unpleasant programs in public places, such as restaurants, can get up and leave. But the man on the streetcar has no choice but to sit and histen, or perhaps to sit and try not to histen."141 Thus, a state transit agency inay prohibit political advertising altogether on streetcars. ${ }^{142}$ Similarly, a inunicipality's total ban on "loud and raucous" sound trucks roaining the public streets is constitutional because householders could not escape the loud and raucous amplified sound. ${ }^{143}$

Where hearers have some ability to escape or control speech, however, the state may not presumptively ban it. It must leave the decision to the hearer and not to itself. For example, a person offered a handbill is not captive because she can simply decline to take it. ${ }^{144}$ Sinnilarly, the Court in Martin v. Struthers ${ }^{145}$ refused effect to a blanket prohibition on solicitors ringing door bells. But the Court noted that the city could constitutionally enact a regulation enforcing a householder's expressed wish to be left alone: "This or any similar regulation leaves the decision as to whether distributors of hiterature may lawfully call at a hoine where it belongs-with the hoineowner himself." 146 The Court again empha-

Rediscovering the Defamation of Groups, 1974 SUP. CT. REv. 281, 282-83; see also Stone, Fora Americana: Speech in Public Places, 1974 SuP. CT. REv. 233 (discussing public forum coneept).

137. Erznoznik v. City of Jacksonville, 422 U.S. 205, 209 (1975) (holding that statute prohibiting drive-in theatres from exhibiting films containing nudity when screen visible from a public street not enforceable under captive audience rationale).

138. Cohen v. California, 403 U.S. 15, 21-22 (1971) ("the mere presumed presenee of unwitting listeners or viewers does not serve automatically to justify curtailing all speech capable of offense" when viewers could have avoided bombardment "simply by averting their eye").

139. Erznoznik, 422 U.S. at 211-12 (drive-in theatre displaying films with nudity are not "so intrusive as to make it impossible for an unwitting individual to avoid exposure to it").

140. Lehman v. City of Shaker Heights, 418 U.S. 298, 302 (1974) (plurality opinion).

141. Id. at 307 (Douglas, J., concurring) (emphasis in original).

142. Id. at 303-04.

143. Kovacs v. Cooper, 336 U.S. 77, 86-87 (1949).

144. Id. at 86-87; see Schneider v. State, 308 U.S. 147, 162 (1939).

145. 319 U.S. 141, 149 (1943).

146. Id. at 148; see also Rowan v. United States Post Office, 397 U.S. 728, 737 (1970) ("The Court has traditionally respected the right of a householder to bar, by order or notice, solicitors, 
sized lack of opportunity for the hearer to refuse speech when it rejected a facial challenge to a nunicipal ban on residential picketing in Frisby $v$. Schultz: ${ }^{147}$ "The resident is figuratively, and perhaps literally, trapped within the loine, and because of the unique and subtle impact of the picketing is left with no ready nieans of avoiding the unwanted speech." 148

The core notion underlying this line of cases is that the state, although generally restricted fron1 prohibiting speecl, can enforce an individual's private preference not to be accosted for that individual alone. The interest in enforcing a private choice not to hear is contentneutral because the state's interest lies in giving effect to the private preference rather than in prohibiting the substantive content of the regulated speecl. ${ }^{149}$ The civility zone enforces the targeted individual's hiberty interest in being left alone and being able to refuse unwanted speech.

Although householders liave broad license to exclude coinniunication fron their lonies, individuals do not ordinarily have that hiberty interest in public places:

In public places an individual's privacy interests in avoiding offensive communications are generally tlought insubstantial unless the person is deeined a member of a "captive audience", either because the person is literally not free to leave without great burden, or because the person is in a place wliere there is a basic rigltt to remain and where one cannot readily avoid exposure to the unwanted communication. ${ }^{150}$

In public places, we niust therefore avert our eyes or close our ears fronı communications we prefer not to see or liear. ${ }^{151}$

The Court, lowever, las implied that uttering speech in a public forun does not, standing alone, accord absolute protection to the speaker. In Cantwell v. Connecticut, ${ }^{152}$ the Court considered the conviction of Jeliovah's Witnesses who were convicted of soliciting contributions without a permit and breach of the peace. ${ }^{153}$ Cantwell and his sons had ventured into a largely Catholic neighborhood with the intention of selling books and pronulgating their religious views. ${ }^{154}$ They carried

hawkers, and peddlers from his property."); Kovacs, 336 U.S. at 86 (resident can protect self by placing sign on door "that he is unwilling to be disturbed").

147. 487 U.S. 474 (1987).

148. Id. at 487 .

149. The enforcement by the state of a specific individual's liberty interest is quite different from an undifferentiated assertion that certain behavior or speech is "wrong." See R. EPSTEIN, supra note 1, at 331 ("The state qua state has no independent set of entitlements, any inore than a corporation has rights qua corporation against any of its shareholders.").

150. L. TriBE, supra note 51, § 12-19, at 949 n.24 (citations oinitted).

151. Coheu v. California, 403 U.S. 15, 21 (1971) (people wishing to avoid having their sensibilities offended by Cohen's jacket could look away).

152. 310 U.S. 296 (1940).

153. Id. at $300-02$.

154. Id. at 301. 
with then various itens including a phonograph record containing vitriohic criticisn of the Catholic Church, which highly offended several of the persons who heard it. ${ }^{155}$ But the Court held that since Cantwell had asked permission of histeners before playing the record, he could not be convicted of invading the hearer's liberty interests. ${ }^{156}$ Furthermore, the Court found that "he [had not] intended to insult or affront the hearers by playing the record." 157 The Court therefore sharply distinguished Cantwell's "effort to persuade a willing listener to buy a book or to contribute inoney" froin "[r]esort to epithets or personal abuse."158 Thus, in Cantwell, the Court implicitly recognized that forcing speecli upon people in a public forum could legitimately be prohibited by the state.

In the high school context, inoreover, the Court has uplield restrictions on public speech designed to protect impressionable students and to inculcate appropriate standards of behavior. In Bethel School District v. Fraser, ${ }^{159}$ the Court held that a student's first ainendment interests were not violated when he was disciplined for delivering, at a high school assembly, an election speecl that constituted an extended sexual netaplior. The Court in Bethel enforced a state interest that was an amalgam of the captive audience doctrine and an in parens patriae notion that the sclool had an interest in protecting children from sexual speech. ${ }^{160}$ The paternalistic aspect of Bethel is inappropriate as applied to college students, who are generally legal adults. ${ }^{161}$ Bethel's rationale is, nonetheless, similar to assaultive speech on a university cainpus because the state's interest, in part, is justifiable on the grounds that the assenibled students were in some sense captive. ${ }^{162}$

The captive audience strand of first amendinent doctrine-allowing individuals to exclude some unwanted speecl in sonie situations-lays the doctrimal foundation for recognition of a personal civility zone. The boundaries of that zone must be quite narrow in public forums. The zone need only be broad enough to protect individuals from having assaultive speech forced upon then. Protecting this zone for university students is particularly appropriate because they, like householders, have limited practical freedon to leave. They are not only "in a place where

155. Id. at $301,309$.

156. Id. at 308-09.

157. Id.

158. Id. at 309-10.

159. 478 U.S. $675,680-86$ (1986).

160. Id. at 681-86. The Court paid particular attention to the fact that young girls were in the audience. Id. at 683 .

161. Note, Racist Speech on Campus: A Title VII Solution to a First Amendment Problem, 64 S. CAL. L. Rev. 105, 124-25 (1990) (authored by Ellen E. Lange) (in parens patriae no longer applicable to students at the modern university).

162. See infra text accompanying notes $213-20$ (arguing that university students are, to some extent, as a practical matter, captive on the university campus). 
there is a basic right to remain,"163 but they must also physically be on campus to complete their education. Unlike householders, however, students are not as rigidly situated in any particular area of the campus unless a specific class or activity so requires. Thus, the definitional bounds of the civility zone require something stricter than mere presence on campus.

By focusing on the hearer's liberty interest in not being harassed rather than the substantive content of the speech, the court can avoid ranking or valuing speech. The court can thereby allow the state university to protect the hearer's hiberty interest in being left alone. ${ }^{164}$ The following Section will attempt to discern when a hearer can be protected from unwanted speech. That is, it explores the boundaries of the civility zone.

\section{Finding a Bright-Line Boundary for the Civility Zone}

The preceding Section argued that the narrow protection afforded by a civility zone finds doctrinal support within the captive audience cases, and that a civility zone exception to first amendment protection of speech should appropriately evolve from that doctrine. The central purpose of a civility zone is to protect hearers from having unwanted speech forced upon them. To flesh out the boundaries of such a civility zone, this Section will examine the tort of intentional infliction of emotional distress which, in some states, ${ }^{165}$ provides recompense for some harms done by group-based epithets. This Section will argue that the tort cases' emphasis on known susceptibility of a victim provides a way to narrow the scope of epithet restrictions to the most harmful incidents, and that the susceptibility doctrine also underscores the especially harnful nature of group-based epithets.

Traditional tort law has long recognized that speech can cause recoverable damage to an individual's nonbodily interests. "[M]edical science has recognized ... that not only fright and shock, but also grief, anxiety, rage and shame, are in themselves 'physical' injuries, in the sense that they produce ... symptoins that are readily visible to the professional eye."166 The law protects individuals agamst some of these harms through its recognition of the actions of libel and slander. In relatively

163. See supra text accompanying note 150 .

164. Content-neutral state interests in restricting speech, properly pursued, are constitutionally permissible. See, e.g., United States v. O'Brien, 391 U.S. 367, 381 (1968).

165. See, e.g., Wiggs v. Courshon, 355 F. Supp. 206, 208 (S.D. Fla. 1973) (verbal abuse); Gomez v. Hug, 7 Kan. App. 2d 603, 604-05, 645 P.2d 916, 917-18 (1982) (tirade of racial epithets while pounding fist on table); see also Love, supra note 82, at 127-45 (collecting sources; most cases involve speech plus conduct, but in some states harassing speech alone held actionable).

166. W. KeEton, D. Dobbs, R. Keeton \& D. OWEn, Prosser \& KeEton on the LAW of TORTS $\S 12$, at 56 (5th ed. 1984) [hereinafter Prosser \& KeEton]. 
recent years, tort law has also recognized an independent tort of "outrageous conduct causing severe emotional distress."167 All but three states have adopted some version of this new tort. ${ }^{168}$ The Restatement (Second) of Torts defines this as conduct that goes "beyond all possible bounds of decency, [and is] atrocious and utterly intolerable in a civilized community. Generally, the case is one in which the recitation of the facts to an average member of the community would arouse his resentment against the actor, and lead him to exclaim, 'Outrageous!' "169 The Restatement, however, exphcitly excludes "mere insults" from recovery because the "rough edges of our society are still in need of a good deal of filing down, and in the meantime plaintiffs must necessarily be expected and required to be hardened to a certain amount of rough language ...."170 Courts have differed on the issue whether racial epithets are "outrageous" or "mere insults." 171

Traditionally, physical injuries were required as corroborative proof of any mental or emotional injury. ${ }^{172}$ Both the Restatement ${ }^{173}$ and niost courts now agree, however, that "[s] $]$ evere emotional distress may be shown either by physical inanifestation of the distress or subjective testimony."174 Nonetheless, courts have not forgotten the function of the physical manifestation requirement as a safeguard on the scope of the

167. See RESTATEMENT (SECOND) OF TORTS \$46 (1977) [hereinafter RESTATEMENT] (describing this variation on the tort of intentional infliction of emotional distress); see also Hustler Magazine, Inc. v. Falwell, 485 U.S. 46, 56 (1988) (action by public figure subject to limitations of New York Times).

168. Annotation, Modern Status of Intentional Infliction of Mental Distress as an Independent Tort; "Outrage," 38 A.L.R. 4TH 998, 1030-31 \& Supp. $62-63$ (1985 \& Supp. 1990) (compilation of cases).

169. RESTATEMENT, supra note $167, \S 46$ comment d.

170. Id. "The liability clearly does not extend to inere insults, indignities, threats, annoyances, petty oppressions, or other trivialities." Id.

171. See supra note 29 and accompanying text; infra notes $193-98$ and accompanying text.

172. See M.B.M. Co. v. Counce, 268 Ark. 269, 273-81, 596 S.W.2d 681, 685 (1980) (tracing development of physical manifestation requirement and concluding that it is all but eliminated).

173. The disjunctive language of section 46 plainly allows for recovery independent of physical manifestation: "One who by extreme and outrageous conduct intentionally or recklessly causes severe emotional distress to another is subject to liability for such emotional distress, and if bodily harm to the otler results from it, for such bodily liarm." RESTATEMENT, supra note 167, $\S 46$ (emphasis added); $c f$. id. comment $\mathrm{k}$, at 78 (severe emotional distress often, but not always, accompanied by plysical symptoms; in order to guard against fictitious claims, ligher degrec of "outrageousness" inay be required where no proof of physical manifestation).

174. Davis v. Gage, 106 Idalio 735, 741, 682 P.2d 1282, 1288 (1984); see also Alcorn v. Anbro Eng'g, Inc., 2 Cal. 3d 493, 498, 468 P.2d 216, 218, 86 Cal. Rptr. 88, 90 (1970) ("the courts of this state have also acknowledged the riglit to recover daniages for emotional distress alone, without consequent plysical injuries, in cases involving extreme and outrageous intentional invasions of one's mental and emotional tranquility"); Waldon v. Covington, 415 A.2d 1070, 1076 (D.C. App. 1980) ("an action for intentional infliction [of emotional distress] may be made out even in the absence of physical injury or impact"); Craft v. Rice, 671 S.W.2d 247, 249 (Ky. 1984) (physical injury may be incidental to the emotional distress, but is not a prerequisite to stating a cause of action); Franklin v. Portland Community College, 100 Or. App. 465, 469, 787 P.2d 489, 491-92 
tort ${ }^{175}$ and may still factor that requirement into determining both the degree of outrageousness and the emotional distress inflicted. ${ }^{176}$ Analogizing the tort to state umiversity anti-slur regulations, victims can be protected from the emotional harm the speaker caused, if the conduct was outrageous and not a "mere insult" or a rough edge in societal interactions.

Neither the law nor university regulations can smooth all the rough edges of society, nor, imdeed, can they force people to like one another. ${ }^{177}$ But the Restatement recognizes as actionable conduct similar to "mere insults" which is not otherwise sufficiently "outrageous." This category encompasses behavior directed toward a person whom the tortfeasor knows to be particularly susceptible to a certain kind of abuse. ${ }^{178}$

This doctrine finds its roots in a 1920 case where pranksters publicly humiliated an eccentric and "mentally deficient" woman. ${ }^{179}$ Sick people, ${ }^{180}$ children, ${ }^{181}$ and pregnant women ${ }^{182}$ have recovered when the tortfeasor, knowing of their particularly vulnerable position, directed profamity or abuse at them, sent them threatening letters, or engaged in "other conduct which apparently would not otherwise have been suffcient to constitute a tort." "183 Some courts have interpreted this doctrine

(1990) (plaintiff's complaint stating no allegations of physical injury sufficient to withstand summary judgment).

175. See M.B.M. Co., 268 Ark. at 273-81, 596 S.IV.2d at 685 (court unwilling to abandon completely the requirement of physical injury); Fisher v. Carousel Motor Hotel, Inc., 424 S.W.2d 627, 630 (Tex. 1967) (no cause of action for intentional infiction of emotional distress where employee called plaintiff a "nigger," but snatching plaintiff's plate sufficient to state a clain for battery).

176. See REstatement, supra note 167 , $\$ 46$ comment $k$.

177. See Prosser \& KeETon, supra note $166, \S 12$, at 59 ("it is still very desirable that some safety valve be left through which irascible tempers may blow off relatively harmless steam") (emphasis added).

178. RESTATEMENT, supra note $167, \S 46$ cornment $f$ (describing the increased injury in. situations involving particularly vuhierable target); see also PrOSSER \& KEETON, supra note 166, $\S 12$, at 59 (same).

179. Nickerson v. Hodges, 146 La. $735,742,84$ So. 37,39 (1920) (awarding victim's next of kin $\$ 500$ in damages).

180. E.g., Meiter v. Cavanaugh, 40 Colo. App. 454, 456, 580 P.2d 399, 400 (1978) (awarding damages to plaintiff lessor, who was "visibly bandaged after recent cancer surgery," when defendant called her a "sick old woman," made unsubstantiated threats of legal influence, and damaged the property he leased from the plaintiff).

181. E.g., Korbin v. Berlin, 177 So. 2d 551, 552 (Fla. Dist. Ct. App. 1965) (reversing defendant's summary judgment where defendant knowingly made the following false statement to a six-year-old girl: "Do you know that your mother took a man away from his wife? Do you know God is going to punish them? Do you know that a man is sleeping in your mother's room?"), cert. dismissed, 183 So. 2d 835 (Fla. 1966).

182. E.g., Vargas v. Ruggiero, 197 Cal. App. 2d 709, 720, 17 Cal. Rptr. 568, 574 (1961) (reversing judgment n.o.v. in favor of defendant where defendant intentionally and unreasonably subjected pregnant plaintiff to emotional distress hikely to cause a misearriage).

183. Prosser \& KeEton, supra note $166, \S 12$, at 63 ; see also Restatement, supra note 167 , $\S 46$ comment $\mathrm{f}$ ("The cônduct may become heartless, flagrant, and outrageous when the actor 
to require only that the victim be generally susceptible to emotional distress and not that the victim be susceptible to the particular abuse perpetrated by the tortfeasor. ${ }^{184}$ Exploiting even an unreasonable sensitivity is sufficient to impose hability if the tortfeasor knew of that sensitivity. ${ }^{185}$

The susceptibility doctrine, however, begs the question of how the speaker knows of the hearer's susceptibility. In certain situations, the speaker will have actual knowledge, for example, that a hearer is gay and has a particular sensitivity to epithets. In other circumstances, knowledge will have to be imputed to the speaker. This will not be terribly difficult: to some degree, the very fact that a speaker chooses a harmful, derogatory, and history-laden ${ }^{186}$ epithet such as "nigger" or "faggot" imphes that he knows of the victim's special sensitivity to the epithet and that the speaker has chosen purposely to capitalize on that sensitivity. ${ }^{187}$ The particular context of the utterance could negate such an inference, ${ }^{188}$ however, and therefore must also be considered.

The essential justification for hability is that the tortfeasor has chosen to exploit a manifest vulnerability. "[B]ecause a person's race is usually obvious, the maker of a racial insult is exploiting an apparent susceptibility rather than causing an unforeseeable mjury, as in the eggshell skull cases." 189 The speaker chooses the group-based epithet precisely because it will have a particularly strong and vicious effect on the victim. ${ }^{190}$ Just as the Court has allowed the subjective state of mind required by the New York Times actual malice standard to be inferred, so too can knowledge of susceptibility be inferred from objective facts. ${ }^{191}$

proceeds in the face of [knowledge of peculiar susceptibility to emotional distress], where it would not be so if he did not know.").

184. See, e.g., Zalnis v. Thoroughbred Datsun Car Co., 645 P.2d 292, 294 (Colo. Ct. App. 1982) (defendant's knowledge that plaintiff had seen her husband kill himself provided sufficient notice to defendant that plaintiff susceptible to emotional distress arising from being called a "French whore").

185. Moniodis v. Cook, 64 Md. App. 1, 15, 494 A.2d 212, 219 ("Where the plaintiff suffers 'exaggerated and unreasonable' distress, however, the requirement is not satisfied, unless the defendant was aware of a particular sensitivity that caused the reaction.") (quoting Harris v. Jones, 281 Md. 560,570 n.2, 380 A.2d 611, 616 n.2 (1977)), cert. denied, 304 Md. 631,500 A.2d 649 (1985); see also Brown v. Ellis, 40 Conn. Supp. 165, 169, 484 A.2d 944, 946 (Conn. Super. Ct. 1984) (denying defendant-employer's motion for summary judgment where employer knew of plaintiff employee's acrophobia and forced him to work at extreme heights).

186. See supra text accompanying notes 10-42 (harms of group-based epithets).

187. See Contreras v. Crown-Zellerbach Corp., 88 Wash. 2d 735, 737, 565 P.2d 1173, 1174 (1977) (agent knew or should have known that target's nationality made him particularly susceptible to emotional distress from racial slurs). But see Dawson v. Zayre Dep't Stores, $346 \mathrm{~Pa}$. Super. 357, 361, 499 A.2d 648, 650 (1985) (calling black plaintiff "nigger" did not exploit a known susceptibility).

188. See infra text accompanying notes 200-03.

189. Delgado, supra note 16 , at 170.

190. See Prosser \& KEETON, supra note $166, \S 12$, at 60 ("there is liability for conduct ... which is especially calculated to cause, and does cause, mental distress of a very serious kind").

191. See Harte-Hanks Communications, Inc. v. Connaughton, 491 U.S. 657, 683 (1989) 
At this point, it unay appear that any time a speaker uses a racial epithet, he will have the requisite knowledge of susceptibility. However, this is not so inuch a blanket rule as a rebuttable inference. ${ }^{192}$ Many courts already recognize that in certain situations racial epithets and racial insults rise above "mere insults" and are "outrageous."193 The Model Coinmunicative Torts Act also provides that a

person who intentionally engages in a course of conduct that is addressed to an individual, that is specifically intended and reasonably likely to harass or intimidate the individual because of the individual's race, sex, [ethnic origin], or religion, and that directly causes serious einotional distress, is subject to hability to the individual [for damages or an injunction]. ${ }^{194}$

Not all jurisdictions, however, find that such comments are outrageous. ${ }^{195}$ Some courts have paid particular attention to the length and

(deliberately closing eyes to conflicting sources supports inference of actual malice); Tiine, Inc. v. Pape, 401 U.S. 279, 285 (1971) (inferential proof of actual malice appropriate where "alleged libel purports to be an eyewitness or other direct account of events that speak for themselves"); St. Amant v. Thompson, 390 U.S. 727, 732 (1968) (imherent inprobability of published report can negate professions of good faith belief in its veracity); Curtis Publishing Co. v. Butts, 388 U.S. 130, 156 (1967) (plurality opinion) (court may infer actual malice by assessing " "the reliability, the nature of the sources of the defendant's information, its acceptance or rejection of the sources, and its care in checking upon assertions." ") (quoting jury instructions given by lower court in Butts case).

192. Some have made the charge that the University of California regulation, supra note 6, creates an "irrebuttable presunption" that the enunerated personal characteristics it lists are fighting words, even though the regulation requires that the "circumstances of their utterance create a hostile and intiınidating environınent." See Comment, supra note 86 , at 852 .

193. See, e.g., Agarwal v. Johnson, 25 Cal. 3d 932, 946, 603 P.2d 58, 67, 160 Cal. Rptr. 141, 150 (1979) (use of epithet "migger" and threats of termination from employment "outrageous"); Alcorn v. Anbro Eng'g, Inc., 2 Cal. 3d 493, 498, 468 P.2d 216, 217, 86 Cal. Rptr. 88, 90 (1970) (racial epithet used by plaintiff's supervisor was "extreine and outrageous"); Ledsinger v. Burmeister, 114 Mich. App. 12, 20, 318 N.W.2d 558, 562 (1982) (merchant's use of racial slurs while ejecting patron froin public establishınent "extreme and outrageous"); Franklin v. Portland Cominunity College, 100 Or. App. 465, 471, 787 P.2d 489, 493 (1990) (racial epithet may amount to more than inere insulting language).

194. The Model Communicative Torts Act, 47 WASH. \& LEE L. REV. 1, 36 (1990) [hereinafter Model Act]. The drafters' bracketing of "ethnic origin" indicates that they disagreed about including the category. Id. at 39.

195. See, e.g., Lay v. Roux Labs., Inc., 379 So. 2d 451, 452 (Fla. Dist. Ct. App. 1980) (defendant's "humiliating language, vicious verbal attacks, racial epithets and [calling] plaintiff a 'nigger' " not sufficiently outrageous to state a claim); Irving v. J.L. Marsh, Inc., 46 Ill. App. 3d 162, 164-67, 360 N.E.2d 983, 984-86 (1977) (finding epithet "arrogant nigger" inscribed on return form presented to plaintiff was "abusive, offensive and indecent," but did not possess "the degree of severity that is necessary to establish a cause of action for intentional infliction of severe einotional distress" despite fact that plaintiff forced to endure humiliation); Bradshaw v. Swaggerty, 1 Kan. App. 2d 213, 214-16, 563 P.2d 511, 513-14 (1977) (epithets "bastard," "nigger," and "knot-headed boy" not outrageous); Dawson v. Zayre Dep’t Stores, 346 Pa. Super. 357, 360, 499 A.2d 648, 649 (1985) (store einployee calling plaintiff-customer a "nigger," while "insulting and abusive," did not amount to extreme and outrageous conduct). But see Love, supra note 82, at 149-50 (proposing a presumption that harassinent or abuse based on status is extreme and outrageous for purposes of sunumary dismissal proceedings). 
calculated nature of verbal attacks. For example, in Gomez v. Hug, ${ }^{196}$ the plaimtiff was subjected to a five-to-fifteen-minute tirade of racial epithets and ordinary vulgarities while the speaker pounded his fist on a table. The court distinguished an earlier case ${ }^{197}$ denying recovery for the use of racial epithets based upon botli the severity of the defendant's language and the length of the attack: "However tasteless such outbursts are, they do not sink to the abysinal degradation of the words used by Hug."198 The test used in this Comment also looks beyond the simple fact of a racial epithet. The entire context must be taken into account, including whether the speech creates a hostile and intimidating environinent, mterfering with the hearer's ability to pursue her education. ${ }^{199}$

Context inust be considered because there will, of course, be occasions where the use of such epithets will not constitute an exploitation of the hearer's susceptibility. For instance, the use of a derogatory term between two members of the "defamed" group is fairly common. ${ }^{200}$ The speaker in that case does not ordinarily intend his action to be offensive in the same way that a person of a different background might. ${ }^{201}$ The liearer rarely takes the action as offensive. Conversely, some group-based epithets are also used as general insults. This is particularly true with slurs based on the target's presumed homosexuality. The speaker often chooses the epithet not because he knows the target to be homosexual, but rather to use the epithet as a general insult. ${ }^{202}$ While the speaker's behavior might be upsetting to the target (and to gay people overhearing it), the speaker might have no reason to suspect that the hearer has a particular susceptibility to the use of that term as opposed to any other "insult." The speaker's behavior would therefore constitute a "mere insult" and fall outside of the "susceptibility" exception to the Restatement's requirement of "outrageous" conduct. Finally, a speaker could conceivably offer proof that a particular hearer was not harmed by the use of the racial epithet. ${ }^{203}$

The susceptibility doctrine provides both a justification for and a

196. 7 Kan. App. 2d 603, 604-06, 645 P.2d 916, 917-20 (1982).

197. Bradshaw, 1 Kan. App. at 214-16, 563 P.2d at 513-14.

198. Id. at 610,645 P.2d at 922; see also Model Act, supra note 194, at 36 (model act requires a "course of conduct" to impose liability).

199. See infra text accompanying note 222 (text of proposed regulation).

200. See Delgado, supra note 16 , at 180 .

201. See id.

202. The speaker implies, of course, that such a sexual orientation would be something highly undesirable. Indeed, courts have often held that the false imputation of homosexuality constitutes defamation. See Annotation, Imputation of Homosexuality as Defamation, 3 A.L.R. 4TH 752 (1981 \& Supp. 1990) (collecting cases).

203. This avoids the problem of assuming that all African Americans or all gay people will be affected, and harmed in the same way, by epithets. But even this assumption would not necessarily weaken the strength of the susceptibility doctrine as a test because its focus on the intent and culpability of the speaker is appropriate if our concern lies in minimizing the speech chilled by any 
limit upon the scope of restricting group-based epithets. It justifies such restrictions because the speaker using epithets has a higher level of culpability than one using ordinary insults. The speaker is culpable because she acted with specific intent to harm the victim by exploiting an apparent or known susceptibility. Ordinary insults, which do not exploit the victim's particular susceptibility, are not as harmful to the target and do not evidence the saine degree of culpability on the part of the speaker. Thus, by using susceptibility as a test, the regulations can remedy the most egregious class of harms without entering into trivial disputes.

Allowing protection from the inost personally abusive verbal assaults accords in principle with the strict standard of New York Times. ${ }^{204}$ Like the actual malice requirement enunciated in that case, the civility zone redresses the most egregious speech harms-those committed with specific intent to harm-and provides some protection to victims. Yet, at the same time, the civility zone leaves wide latitude for freedom of speech.

Moreover, as Prosser and Keeton observed, the problems of fraudulent clains and proof of damages for intentional infliction of enotional distress (which may also dog enforcement of the civility zone) are no different froin those presented by "ordinary" physical injuries:

It is the business of the law to remedy wrongs that deserve it, even at the expense of a "flood of hitigation," and it is a pitiful confession of incompetence on the part of any court of justice to deny rehief on such grounds. ... So far as distinguishing true claims from false ones is concerned, what is required is rather a careful scrutiny of the evidence supporting the claim; and the elimination of trivialities calls for nothing more than the same common sense which has distinguished serious from trifling injuries in other fields of the law. ${ }^{205}$

Although factual determinations may be troublesome or the first amendment questions difficult, the courts should not ignore altogether the harms inflicted by group-based epithets.

\section{State Universities Are Particularly Justified in Protecting Their Students From Group-Based Verbal Abuse}

The Restatement also allows recovery for conduct that is less than outrageous, in situations where the defendant stands in a relationship of

particular regulation. It would only chill that speech used with specific intent to harass and intimidate.

204. New York Times Co. v. Sullivan, 376 U.S. 254, 279-80 (1964) (recovery allowable for those false statements made with actual malice).

205. Prosser \& Keeton, supra note $166, \S 12$, at 56 (footnotes omitted); see also Delgado, supra note 16, at 165-70 (difficulty in measuring and apportioning damages not sufficient objection to prevent recognition of a tort for racial insults). 
authority over the plaintiff. ${ }^{206}$ This relationship must be one of custody or subordination, real or assumed. ${ }^{207}$ A duty to treat the plaintiff in a particular way, such as that owed by an innkeeper or a common carrier to its patrons, will subject the defendant to the higher standard of conduct. $^{208}$

Under this rationale, employers have a special duty to treat their employees with dignity and to protect them from abuse by fellow einployees. ${ }^{209}$ Not unlike the first amendment captive audience doctrine, ${ }^{210}$ the justification for imposing a duty upon employers to provide a working environment free of abuse flows from the fact that employees' freedom to escape is, as a practical matter, quite himited. ${ }^{211}$ Forcing someone to tolerate abuse $\mathrm{m}$ an environment from which she is unable as a practical matter to escape is especially heinous. ${ }^{212}$ Inasmuch as the university regulations punish students for abuse directed at university employees, the application of this doctrine is straightforward. The affirmative interest im protecting employees of the university from abuse would provide the university with a justification for pumishing members of the community who harass or assault those employees.

206. See RESTATEMENT, supra note 167 , $\$ 46$ comment e.

207. See id.; Prosser \& KEETON, supra note $166, \S 12$, at 61.

208. RESTATEMENT, supra note 167, § 48; see also Wiggs v. Courshon, 355 F. Supp. 206, 209 (S.D. Tex. 1973) ("an insult to a patron by an employee of a common carrier, innkeeper or public utility is actionable").

209. See Dominguez v. Stone, 97 N.M. 211, 212, 215, 638 P.2d 423, 424, 427 (N.M. Ct. App. 1981) (employment relationship is a significant factor in determining imposition of liability); Contreras v. Crown-Zellerbach Corp., 88 Wash. 735, 741, 565 P.2d 1173, 1176 (1977) ("When one in a position of authority . . . over another has allegedly made racial slurs and jokes and comments, this abusive conduct gives added impetus to the claim of outrageous behavior. The relationship between the parties is a significant factor in determining whether liability should be imposed.") (citation omitted). For further examples of employers subjecting employees to racial epithets, see Agarwal v. Johnson, 25 Cal. 3d 932, 941-42, 603 P.2d 58, 64, 160 Cal. Rptr. 141, $146-47$ (1979) (terminated employee called "black nigger, member of an inferior race"); Alcorn v. Anbro Engineering, Inc., 2 Cal. 3d 493, 498, 468 P.2d 216, 218-19, 86 Cal. Rptr. 88, 90-91 (1970) (plaintiff's supervisor called him "goddam nigger" and fired him); Gomez v. Hug, 7 Kan. App. 2d 603, 604-05, 645 P.2d 916, 917-18 (1982) (plaintiff employee subjected to tirade lasting between 5-15 minutes calling him a "fucking spic," "Mexican greaser" and a "pile of shit"). But see McIsaac v. WZEW-FM Corp., 495 So. 2d 649, 651 (Ala. 1986) (recovery denied where superior repeatedly solicited sexual relations from female employee).

210. Cf. Lehman v. City of Shaker Heights, 418 U.S. 298, 302 (1974) ("The streetcar audience is a captive audience. It is there as a matter of necessity, not of choice.").

211. In Contreras, the court stated:

Where a person is not free to leave but must remain in physical proximity to others who continually make racial slurs and comments, it is for the jury to determine both whether this is a factor in making the claim one of extreme outrage and the extent to which the employer was or should have been aware of these conditions through its supervisory personnel or by other means.

Contreras, 88 Wash. 2d at 741, 565 P.2d at 1176-77; see also Dominguez, 97 N.M. at 215, 638 P.2d at 427 (citing above langnage with approval).

212. Contreras, 88 Wash. $2 \mathrm{~d}$ at 741,565 P.2d at $1176-77$ (characterizing such a situation as a factor weighing towards "extreme outrage"). 
The application of this doctrine to abuse of one student by another student raises a more difficult issue. Although an analogy to the confines of the workplace appears at first glance somewhat strained for university students, the student-umversity relationship does in fact share many characteristics of the employment relationship which make both of special concern. ${ }^{213}$ Neither employees nor students are really captive in the sense that they lack the legal right or the physical ability to leave the environment. Both the workplace and the umversity are best described as "discrete, definable 'experiences," " rather than as physical relationships of person to locale. ${ }^{214}$ Workers and students alike are defined by their overall relationship to the institution.

Both employees and students are required as a practical economic matter to reniam at the workplace or on the cainpus. ${ }^{215}$ Like an employee working on an employer's premises, students have an economic need to remain on campus. ${ }^{216}$ Umiversity degrees and the knowledge

213. See Note, supra note 161 , at $\mathbf{1 2 5 - 2 7}$ (proposing regulation modeled on title VID).

214. Id. at 127.

215. As the technological and informational aspects of American society become increasingly complex, a college education is imcreasingly necessary both for individual workers and for the wellbeing of society. Kerr \& Gade, Current and Emerging Issues Facing American Higher Education, in Higher EdUCATION IN AMERICAN Society 111, 114 (P. Altbach \& R. Berdahl eds. 1981). Froin 1900 to 1980, the proportion of workers in "technical, managerial, and professional" classifications has risen from $10 \%$ to $25 \%$ and is likely to continue to rise. Id.; see also Note, supra note 161, at 125 (in modern society, college education is no longer a luxury but a necessity) (citing Wright, The Constitution on Campus, 22 VAND. L. Rev. 1027, 1032 (1969)); see also Contreras, 88 Wash. 2d at 741, 565 P.2d at 1176-77 (einployee not free to leave but must remain in workplace).

216. Note, supra note 161, at 134 ("A college education is the one key that will unlock the door to a decent job and a decent future for many individuals. This reality underscores the importance and necessity of extending to the campus concepts that by now are well accepted in the workplace.").

The authors of Comment, supra note 86, at 902 n.377, argue, however, that it is "incoherent" to equate the college campus with the workplace because the student's job (should she choose to place herself in a public forum on campus) is, untike ordinary occupations, "to consider and analyze ideas that may be expressed in potentially offensive remarks." A student does not, however, attend the university in order to be a walking dart board upon which others may cast abusive speech. Rather, it is the student's task to study and, if she chooses, to participate in extracurricular activities. Along the way, she may perhaps even like to eat her lunch unaccosted in a campus square. Although exposure to ideas she finds offensive may indeed be part of her university experiencc (as may her ability to propound ideas others consider offensive), she need not be left unprotected from personally assaultive speech in order to accomplish or even facihtate that interchange of ideas.

Furthermore, the counterargument that a student is not captive to some extent on campus because higher education is unnecessary to survival or to self-realization for other people, see id., misses the point. The university functions, to varying degrees, as a gatekeeper for entry to the professions, academia, and other societally influential and desirable positions. D. BoK, BEYOND THE IVORY TOWER 64 (1982). A student desiring those options, whether for reasons of reinuneration or self-realization, has no choice but to attend the university. This rationale is perfectly consistent with the employment discrimination laws. Surely, Ann Hopkins, for example, could have gone somewhere else than Price Waterhouse to become a partner in an accounting firm or simply to earn her living. Nonetheless, her choice to seek a partnership in that aecounting firm was protected. See Price Waterhouse v. Hopkins, 490 U.S. 228 (1988) (woman's title VII claim that accounting firm declined to make partnership decision for two years assumed cognizable). Similarly, 
they represent are, like employment, scarce economic resources. ${ }^{217} \mathrm{~A}$ university environment free of harassment and intimidation is particularly crucial because students need to devote their attention and energy to their studies rather than to reacting to a hostile and threatening environment. Abused and harassed students require the university's protection because, like employees, they are subordmate members of the institution, are vulnerable to dismissal, and have little power of their own to reniedy wrongs against them. ${ }^{218}$

Thus, for the same reason that a court might impose a duty on a state umiversity to protect its students from abuse, the umversity can articulate an interest im protecting its students im order to justify an antislur regulation. Like an employer who is lield responsible for the abuse of one employee by another employee, ${ }^{219}$ the umversity stands in a position of responsibility vis-à-vis botlı victim and victimizer when botlı are affiliated with the imstitution. Workplace and umversity abuse are especially invidious because the victim has no choice, as a practical matter, but to work or to attend school. 220

The "special relationslnip" doctrine clarifies the interest of a state urviversity im protecting its students from personally targeted abuse. Taken as a wliole, the tort doctrine of imtentional infliction of emotional distress provides a constitutionally permissible model for state university codes of conduct to prohibit personally abusive, face-to-face verbal attacks.

\section{E. Summary and Proposed Regulation}

The susceptibility doctrine and specific intent of the speaker can be

\footnotetext{
Rosalie Tung could have pursued other career options besides that of university professor, but nonetheless she was protected from race and gender discrimination under title VII. See University of Penn. v. EEOC, 110 S. Ct. 577 (1990) (female professor's claim for race, gender, and national origin discrimination under title VII assumed cognizable). The choice of college students, participating in a necessary endeavor to achieve their own occupational and self-realization goals, should be similarly protected.

217. See Note, supra notc 3, at 313-14 (university distributes scarce economic resources in form of knowledge and degrees).

218. See id. at 327-28.

219. E.g., Contreras, 88 Wash. 2d at 736-37, 565 P.2d at 1174 (liability for racial jokes, slurs, and comments made by defendant-employer's employees and agents at the workplace).

220. More difficult questions arise when a student directs group-based epithets against another student while both parties are not on campus. Student conduct codes are often applicable in offcampus locations when a school-sponsored event takes place off campus or at facilities operated by school-affiliated organizations such as fraternities or sororities. See, e.g., UNIVERSITY of California, Berkeley, Office of Student Conduct, Berkeley Campus Regulations IMPLEMENTING UNIVERSTTY PoliCIES $\S 421$ (1985) (defining areas adjacent to campus in which students are subject to university discipline for some breaches of the student code of conduct). Resolution of this question would reduce to a factual determination whether thc educational purposes of the university are sufficiently implicated for the university justifiably to punish the offending student.
} 
used to define a narrow civility zone in which an individual's liberty interest in being left alone can be constitutionally enforced by a state university code of student conduct. The susceptibility doctrine provides a principled distinction with which to single out only the worst cases for punishment, avoiding any equal protection or underinclusiveness probleins which might arise with regulations distinguishing abuse directed at nneinbers of oppressed groups froin abuse directed at ineinbers of nonoppressed groups. Only those utterances targeted at a particular individual or identified group of individuals, ${ }^{221}$ in a context creating an intimidating and hostile environment, which the speaker knew or should have known would greatly upset the target, can be punished. The susceptibility test thereby eliminates problems of inadequate notice and vagueness because it focuses on what the speaker actually knew or should liave known would harm the targeted hearer.

While a test keyed to the susceptibility doctrine may not redress all abusive speech toward university students, it will allow punishment for those instances where the speaker's culpability is highest (equivalent to specific intent), where the speech is inost likely to be injurious because the hearer is particularly susceptible, and where the incident by its nature interferes with the hearer's full participation in the university. Such a test, like the captive audience doctrine, will allow soine protection of the targeted hearer's hiberty interests while minimizing the risk to first amendinent freedoms. The University of California's regulation, ${ }^{222}$ modified in accordance with the principles offered in this Comment, would prohibit

the targeting of one student by another using those personally abusive epithets or words that, when directly addressed to any ordinary person, are, in the context used and as a matter of common knowledge, likely to intimidate and harass the targeted person on the basis of the target's known or apparent race, ethnicity, religion, sex, sexual orientation, disability, or other personal characteristic. For speech to be "targeted" at an individual or an identified group of persons, the circuinstances of the utterance must be such that the speaker directs the speech at particular person(s) in a manner that the ordinary person should reasonably know is likely to be understood as directed at the target (and not to the world at large), thereby creating a hostile and intimidating environment interfering with the target's ability to pursue effectively his or her education or otherwise to participate fully in University programs and activities.

The University of California's pohcy, so modified, eliminates reliance on responsive violence by the target. Instead, it focuses on the speaker's capitalization on a known susceptibility to attack the targeted

221. See infra Section III(B) (discussing "targeting" groups of persons).

222. See California Policy, supra note 6. 
hearer. Its reach is further narrowed by the requirement that, in addition to beimg targeted at a particular individual, the speech create a hostile environment which the speaker should know would interfere with the target's ability to participate as a full inember of the university community.

Umiversities are particularly justified and perhaps required to protect their students from assaultive and degrading speech. Like einployees in the workplace, students must be on campus as a practical econornic matter to receive scarce commodities of knowledge, education, and credentials. Like employees, they are the least powerful meinbers of the unversity community and have hittle ability on their own to protect theinselves. Thus, it is appropriate for a state university to create and enforce a personal civility zone that protects inembers of the university community from personally directed, assaultive speech.

\section{III \\ Application to Some Difficult Cases}

This Part will apply the principles developed in this Cominent to some concrete factual situations. Soine of the situations are drawn from decided cases, and others are hypothetical. Each is designed to illustrate a difficult, borderline case which inight arise under a state university anti-slur regulation.

\section{A. Doe v. University of Michigan}

Doe v. University of Michigan ${ }^{223}$ offers a plain example of a university's attempt to punish the expression of an idea under the guise of a speech harm. Doe was a psychology graduate student who advocated open discussion of theories positing biological differences between the races and the sexes. ${ }^{224}$ Since soine of his ideas might have been considered racist or sexist, he felt potentially subject to discipline under the University's harassinent policy and sued for a declaratory judgment against the Umiversity of Michigan. ${ }^{225}$

Although the university never subjected Doe himself to disciplinary action, the court noted two other instances of sanctioned conduct. A graduate student in the department of social work was called to a formal disciplinary hearing to discuss assertions made in a research class about the "disease" of homosexuality and his plan to cure it. ${ }^{226}$ Another student was informally sanctioned for reading a limerick that "ridiculed a

223. 721 F. Supp. 852 (E.D. Mich. 1989).

224. Id. at 858 .

225. Id. For the text of the University of Michigan's regulations, see supra note 6.

226. Doe, 721 F. Supp. at 865. 
well-known athlete for his presumed sexual orientation."227 An administrator persuaded this student to attend "an educational 'gay rap' session," to write a letter of apology to the student newspaper, and to apologize to the class. ${ }^{228}$ The district court held that Michigan's scheme abridged free speech since it could be apphed to conduct such as Doe's. ${ }^{229}$

Under the principles offered in this Comment, the Doe case was correctly decided. While Doe's ideas regarding race and gender are scientifically disreputable, the umiversity was attempting to serve a broad social purpose-preventing the spread of those ideas-by punishing his speech. Similarly, although the limerick read by the other student did attack an individual, that individual apparently was not present in the class when the perpetrator read it. The harm the university regulations may legitimately seek to address is not slander but the intimidation and harassment accomplished by targeted epithets; the emotional distress suffered by the student athlete is of a lesser magnitude when he is not present to hear the remark. ${ }^{230}$ The culpability of the speaker is therefore too low to warrant pumishment for any attack on the athlete. ${ }^{231}$ In any case, this fact situation fails the "targeting" prong of the test proposed by this Comment. The speaker did not direct the epithet at the athlete and there was no evidence that the incident resulted in an intimidating educational environment for the athlete. If the speaker had directed the limerick to the face of the athlete, it would be far more likely that the speaker had acted with specific intent to harass the athlete. Similarly, a better case of targeting would be presented if the speaker mailed a written copy of the limerick to the athlete.

As this Comment's analysis of Doe demonstrates, umiversities can protect victims of group-based epithets on campus without chilling classroom discussion since only personally directed, targeted epithets can be puinished under the civility zone rationale. ${ }^{232}$ Abstract or theoretical dis-

227. Id.

228. Id.

229. Id. at 853-54.

230. Cf. Dillon v. Legg, 68 Cal. 2d 728, 740, 441 P.2d 912, 920, 69 Cal. Rptr. 72, 80 (1968) (location of plaintiff at actual scene of relative's injury is one decisive factor in granting damages for infliction of einotional distress).

231. Moreover, the student athlete was possibly a public flgure and therefore subject to comment, parody, or ridicule. In defamation cases where the plaintiffs are students who hold prominent student government offices, defendants have inade this argument with varying degrees of success. Compare Diaz v. Oakland Tribune, Inc., 139 Cal. App. 3d 118, 134-35, 188 Cal. Rptr. 762, 772-73 (1983) (question of fact whether plaintiff community college student body president "opened her private life" to public coinment by accepting that office) with Frasca v. Andrews, 463 F. Supp. 1043, 1052 (E.D.N.Y. 1979) (high school student-body vice-president not a public figure because subjecting hiln to "witlering spotlight of the press" would not serve educational and democratic values).

232. Cf. FCC v. Pacifica Found., 438 U.S. 726, 743 n.18 (1978) (plurality opinion) ("A 
cussions are not generally understood to target a particular individual. To avoid facial challenges under the first amendment such as the one that succeeded in Doe, universities nust therefore take great care in drafting and implementing anti-slur regulations so that they apply only to that narrow class of speech harms. ${ }^{233}$ Such narrowly drafted regulations can protect the free speeeh interests of speakers from being unduly infringed without sacrificing wholesale the victim's interest in being let alone.

\section{B. Verbal Assaults on More Than One Person}

A speaker acting with specific imtent to exploit a known susceptibility can harm an identified group of people when an epithet inflicts harm on each of them in the same inanner as if it were addressed to a single individual. The key determination is whether the speaker intended to target a group of identified individuals, as opposed to a social group sharing common characteristics. Punishing a speaker for such behavior is in substance no different than punishing her for the harm she did to any individual member of the targeted group. It is sharply in contrast to punishing her for "group hbel," which sanctions a speaker for defaming a societal class of persons sharing a common characteristic such as race or sexual orientation.

The bigger the group, the less likely it may be that the speaker can be punished. But determining when a group has become too large is a difficult inquiry. The law of defamation has long struggled with this question under the requirement that a defamatory statement be "of and concerning" an imdividual. ${ }^{234}$ Although some courts have applied a bright-line rule denying recovery to individuals when the group defamed consists of inore than twenty-five people, most courts apply a variety of

requirement that indecent language be avoided will have its primary effect on the form, rather than the content, of serious communication. There are few, if any, thoughts that cannot be expressed by the use of less offensive language.").

233. Unless carefully drafted and implemented, the potential chilling effect on unpopular opinions would be substantial. Irving, supra note 7, at A16, cols. 3-4 (Professor Gunther of Stanford University states that university's anti-slur regulation chills expression of opinions critical of affirmative action).

234. See Riesinan, Democracy and Defamation: Control of Group Libel, 42 Colum. L. Rev. 727, 759-60 (1942) (addressing "of and concerning" requirement); Coinment, Group Defamation and Individual Actions: $A$ New Look at an Old Rule, 71 CALIF. L. REv. 1532, 1536-39 (1983) (authored by Ellyn Tracy Marcus) (criticizing application of the "of and concerning" requirement, which precludes individual actions for group defamation). 
factors. ${ }^{235}$ The sheer size of the group is itself an important factor. ${ }^{236}$ Thus, although determining whether the speaker has indeed targeted an identified group of persons can be difficult factually, courts already apply this process in the defaination context.

Punishing an individual for verbally attacking an identified group of people should not be confused with "group libel" laws, which punish deprecatory remarks about social groups rather than protecting particular injured individuals. ${ }^{237}$ The Court in Beauharnais v. Illinois ${ }^{238}$ upheld a conviction under a statute that prohibited speech exposing "citizens of Illinois of the Negro race and color to contempt, derision, or obloquy."239 Beauharnais and his compatriots were convicted under the statute for distributing leaflets that included the following language: " 'If persuasion and the need to prevent the white race froin becoming mongrelized by the negro will not unite us, then the aggressions . . . rapes, robberies, kınves, guns and marijuana of the negro, surely will." "240

In the wake of New York Times ${ }^{241}$ and its progeny, it does not seein likely that a statute similar to the one upheld in Beauharnais could survive scrutiny. The Court has repeatedly stated that, under the first ainendment, "there is no such thing as a false idea." 242 The Court in Beauharnais, however, justified its decision on the questionable notion that "if an utterance directed at an individual may be the object of criminal sanctions, we cannot deny to a State power to punish the sanie utter-

235. Compare Blatty v. New York Times Co., 42 Cal. 3d 1033, 1046, 728 P.2d 1177, 1185, 232 Cal. Rptr. 542, 550 (1986) (applying rule of 25 to bar claim arising out of alleged omission of plaintiff's book from defendant's best-seller list), cert. denied, 485 U.S. 934 (1988) and Noral v. Hearst Publications, Inc., 40 Cal. App. 2d 348, 350, 104 P.2d 860, 862 (1940) (individuals cannot state claim arising out of alleged defamation of umbrella group composed of 162 different organizations where there is no certainty as to the individuals accused) with Brady v. Ottaway Newspapers, Inc., 84 A.D.2d 226, 228, 236-37, 445 N.Y.S. 2d 786, 788, 793 (1981) (rejecting rule of 25 and applying flexible "intensity of suspicion" test, lolding that reference to unindicted inembers of police department-whiclt was at least 53 people-sufficient to survive motion for summary judgment).

236. Neiman-Marcus Co. v. Lait, 107 F. Supp. 96, 100 (S.D.N.Y. 1952) (discussing low large a group can be defamed under the common law).

237. See Arkes, supra note 136, at 283 (Because group libel applies to more than the defamation of individuals, "it has moved beyond the plane of private quarrels to disputes that are more nearly public and 'political' in nature."). But see Note, supra note 114, at 309-14 (discussing the history of group libel and arguing that some manifestations mjure individuals sufficiently to justify legal regulation).

238. 343 U.S. 250 (1952).

239. Id. at 252. But see Terminiello v. City of Chicago, 337 U.S. 1, 5 (1949) (overturuing conviction for breach of the peace based on ground that speech "stirred people to anger, invited public dispute, or brought about a condition of unrest").

240. Beauharnais, 343 U.S. at 252 (omission in original).

241. New York Times Co. v. Sullivan, 376 U.S. 254 (1964).

242. See, e.g., Gertz v. Robert Welch, Inc., 418 U.S. 323, 339 (1974). But see Milkovich v. Lorain Journal Co., 110 S. Ct. 2695, $2706-07$ (1990) (rejecting separate layer of protection for "opinion" beyond requirements of New York Times). 
ance directed at a defined group ...."243 This is tenuous because there is a difference-both legally, within the "of and concerning" requirement, and as a matter of common sense-between defaming an identified group of people and a societal class of persons. ${ }^{244}$

Although the Court in Beauharnais used the phrase "defined group,"245 it could not have been speaking of a group of actually identified individuals beyond the entire class of African American people in Illinois because Beauharnais' fliers were addressed not to black individuals but to " 'self respecting white people." "246 Thus, the harm punished by the statute was the expression of Beauharnais' odious ideas and not the harm done to particularly susceptible, targeted hearers. Justice Black recognized this distmction in his dissent (even if he ascribed more deliberativeness to Beauharnais and his group than they deserved) when he wrote that the leaflets distributed by Beauharnais were not simple racial epithets, but rather were a "genume effort to petition their elected representatives."247

The principles offered in this Coinment could not legitimately punish group hibel because punishing the speaker would not redress any particular individual's injury. The essential problem with the Beauharnais statute lay in its infringement upon mdividual interests to serve a societal goal: the elimination of odious attitudes toward African Americans. The harm done to any particular individual was too diffuse. Thus, since no particular individual was harmed, the state could only point to the offensiveness of the ideas contained in the pamphlet as a justification for their suppression. ${ }^{248}$ Yet in that case, the market is available to refute those ideas with more speech and thereby provide a remedy. ${ }^{249}$ The first amendment therefore protects the speech from governmental suppression. ${ }^{250}$

In a case presenting a problein similar to Beauharnais in terms of targeting, American Nazi party members picked as the site of a march the Village of Skokie, which had a high concentration of Jewish residents

243. Beauharnais, 343 U.S. at 258.

244. But see Note, A Communitarian Defense of Group Libel Laws, 101 Harv. L. Rev. 682, 691 (1988) ("Group vilification" can harm individuals by relying on notion that "[p]ermitting group vilification harms the political community as a whole because it denigrates the ideal of equality. Equality is inherent in the concept of coinmurity; having a community consists in recognizing an individual's claim to belong by virtue of a capacity shared equally with other nembers.").

245. Id. at 258 .

246. Id. at 252.

247. Id. at 267 (Black, J., dissenting).

248. But see supra note 114 and accompanying text (discussing alternative interpretations).

249. See Terminiello v. City of Chicago, 337 U.S. 1, $4-5$ (1949) (free exchange of ideas is essential to inaintaining the vitality of civil and political institutions).

250. See Note, supra note 114, at 319-22 (arguing that the underlying theory of the first amendment protects speech whenever the speech can and should be the subject of public dehiberation). 
and Holocaust survivors, because the marchers knew their speech would be maximally offensive there. ${ }^{251}$ They did not, however, target a particular individual:

The permit application stated that the march would last about a half hour, and would involve 30 to 50 demonstrators wearing uniforms including swastikas and carrying a party banner with a swastika and placards with statements thereon such as "White Free Speech," "Free Speech for the White Man," and "Free Speech for White America."252

Despite the subjective intent of the marchers to pick the most offensive locale for their march, ${ }^{253}$ that subjective intent cannot change the lack of individual targeting as a factual inatter. If an entire village could be "targeted," then the word would lose all meaning as a control on the scope of a legitimately protected personal civility zone. If the marchers had planned to accost individual residents with their signs, however, then the state's interest in protecting a civility zone could have been enforced. ${ }^{254}$ Absent such personal targeting, the potential is too great of infringing upon the speaker's free speech interest in order to further societal goals that reach far beyond the immediate harm of the speaker's activity. $^{255}$

All this is not to say, of course, that group libel or otlier speech advocating hatred and mistreatment of people based upon their race, gender, sexual orientation, or any other personal characteristic is not harmful. It surely is. Just as the rhetoric of race liatred was used successfully by the Nazis to help initiate their reign of terror, ${ }^{256}$ the evil ideas proinulgated by hate speech in inodern America help perpetuate societal inequities and discrimination. ${ }^{257}$ But the first amendmentunique in the world-presumes that speech cannot be sanctioned except

251. Collin v. Smith, 578 F.2d 1197, 1199, 1206-07 (7th Cir.), cert. denied, 439 U.S. 916 (1978); A. NEIER, DEFENDING MY ENEMY 38 (1979).

252. Collin, 578 F.2d at 1200 .

253. A. NEIER, supra note 251, at 38.

254. Anonymous phone callers made threatening communications to some Skokie residents who had Jewish surnames. Collin, 578 F.2d at 1216 (Sprecher, J., concurring in part and dissenting in part). These calls, of course, would satisfy the individual targeting requirement even under existing doctrine. See, e.g., Rowan v. United States Post Office, 397 U.S. 728, 736-37 (1970) (honseholders can exclude communication from home); Kovacs v. Cooper, 336 U.S. 77, 86-87 (1949) (plurality opinion) (right of free speech does not protect loud and raucous amplified sound directed at unwilling listeners).

255. See, e.g., Collin, 578 F.2d at 1205 (court rejected Village's argument that policy of fair housing requires prohibition of racially defamatory speech).

256. See Riesman, supra note 234, at 728-29.

257. See M. KIRK \& H. MADSEN, supra note 13, at 120-33 (group-based epithets are unportant to the early inculcation of prejudicial attitudes in children and also to continuing reinforcement of those attitudes); Lasson, supra note 107, at 114-16 (expressive behaviors such as hurling racial epithets, painting swastikas, and burning crosses are part of the "economy of thought" pronoting and reinforcing racism throughout history). 
in the inost extraordinary circuinstances. ${ }^{258}$ A conception of the first amendment that allows the government to redress speech harms when the inarketplace of ideas cannot provide a remedy is just such a circuinstance. Speech targeted at a particular individual and calculated to harm and intimidate that individual constitutes a speech harm not remediable by the inarket. Group vilification and group libel, on the other hand, are susceptible to correction by coinpeting communication because their larm lies in their substantive content rather than their calculated effect upon a particular person. ${ }^{259}$

\section{State v. Phipps}

State v. Phipps ${ }^{260}$ presents an interesting test because it used the fighting words doctrine of the Chaplinsky case to justify a statute singling out a minority group for punishment. ${ }^{261}$ In Phipps, the Ohio Supreme Court upheld a statute prohibiting unwanted loonosexual solicitations. ${ }^{262}$ The statute provided that: "No person shall solicit a person of the saine sex to engage in sexual activity with the offender, when the offender knows such solicitation is offensive to the otiner person, or is reckless in that regard."263 The court convicted Phipps under the statute when he propositioned an undercover police officer. ${ }^{264}$ The court justified its holding by interpreting the statute to reach only fighting words as defined by Chaplinsky and held the statute, so interpreted, not violative of constitutional guarantees. ${ }^{265}$

The principles offered in this Coinment illustrate that Phipps was wrongly decided for several reasons. First, there was no evidence that Phipps could have known that the stranger he solicited would find the solicitation offensive. ${ }^{266}$ Thus, Phipps did not exploit a known susceptibility. Second, a speaker does not ordinarily intend the solicitation to degrade and offend the hearer. It is, in fact, quite the opposite because the speaker may be expressing attraction to the target. ${ }^{267}$ However, once

258. See, e.g., Time, Inc. v. Pape, 401 U.S. 279, 290-92 (1971) (fact that abuse of the protection afforded by New York Times standard may result in erroneous publications not sufficient to justify limiting speech).

259. But see Note, supra note 244 , at 690 (When analyzing group libel, “[i]t is not possible .. . to disregard such sensibilities while still respecting the personhood of the individuals who experience them.").

260. 58 Ohio St. 2d 271, 389 N.E.2d 1128 (1979).

261. Phipps, 58 Ohio St. 2 d at $273,278,389$ N.E.2d at $1131,1133$.

262. Id. at 280,389 N.E.2d at 1134 .

263. Id. at 273,389 N.E.2d at 1131 (citing OHIo Rev. CoDE ANN. $\$ 2907.07$ (B) (Anderson 1975)).

264. Id. at 271,389 N.E.2d at 1130 .

265. Id. at 278-80, 389 N.E.2d at 1133-34.

266. See id. at 271,389 N.E.2d at 1130 (stating facts).

267. See Comment, supra note 71, at 554 (Phipps told the undercover officer that he was " 'handsome,' 'beautiful,' and that he 'really liked' him") (quoting record in Phipps at 10-11). 
the target expresses his offense at such a proposal, ${ }^{268}$ or if the speaker knows of the target's susceptibility to being offended by such a proposal, then the state inay appropriately sanction the actions of the speaker.

A third problem with the statute is that it is underinclusive. The Ohio Supreine Court in Phipps assumed that lomosexual solicitations were per se offensive im every context:

Those who would have this court believe that the average citizen would not find homosexual solicitations of the nature proscribed by [the statute at issue] to be injuriously offensive are guilty of murky thinking. The type of expression proscribed in the statute may have been acceptable in a more barbarous age when luuman dignity had not reached the level expected by citizens in our modern society. ${ }^{269}$

The statute apphies only to same-sex solicitations, but the court ignored the fact that it is equally plausible that homosexuals would be offended by heterosexual solicitations and tliat some people would be highly offended by sexual solicitations of any nature. Even a judge who exhibited distaste for lesbians and gays dissented, recognizmg that a "deviant sexual proposal" (his term) is not akin to a "personally abusive epithet."270 The dissent pointed out a flaw im Phipp's reasoning which parallels Chaplinsky's central flaw: its reliance on likely violence as a standard. This reasoning requires agents of the state, such as police officers and judges, who are as prone to bias as anyone else, to make subjective judgments about when a violent reaction is "reasonable."271

A fourth problem lies in the statute's exclusive protection of majority group ineinbers from minority group insults. Such a result, of course, raises the specter that punishing group-based epithets to protect meinbers of minority groups will, in the long run, backfire against those same groups. ${ }^{272}$ This would turn the "victim's privilege" proposed by Professor Matsuda on its head. ${ }^{273}$ Indeed, the Supreme Court itself has

268. While the facts are not clear in this case, in many situations the speaker would have no reason to know of any such susceptibility if, for example, he meets an undercover officer in a wellknown "pick-up" area.

269. Phipps, 58 Ohio St. 2 d at 277,389 N.E.2d at 1133.

270. Id. at 280-81, 389 N.E.2d at 1135 (Sweeney, J., dissenting).

271. See Comment, supra note 71 , at $567-68$ \& n. 150 .

272. See A. NEIER, supra note 251, at 6 (Jewish author was counsel for the Nazis at Skokie because "[t]he Jews in Skokie require restraints on power to guard themselves [in the long run]"); see also Farber \& Frickey, Is Carolene Products Dead? Reflections on Affirmative Action and the Dynamics of Civil Rights Legislation, 79 CAL1F. L. REv. 685, 699-703 (1991) (discussing Justice Scalia's and Bruce Ackerman's theories which justify using conventional protective rationales of powerless groups to the benefit of inajority groups). For an example of such a "backfire" argunent in the free speech context, see Note, "Offensive Speech" and the First Amendment, 53 B.U.L. REV. 834, 834 (1973) (authored by Kristen Carol Nelson) ("Today many regard the vulgarity in the rhetoric of the radical and black movements with dismay. They find the alleged deterioration in the level of public discourse to be symptomatic of a general decay in the moral and spiritual values of the society at large.") (footnote omitted).

273. See Matsuda, supra note 2, at 2361-64. Matsuda only finds her distinctiou, which grants 
employed the twisted logic that transforms the long history of mistreatment of minority groups into a justification for their continuing mistreatment. 274

It is possible, however, to articulate principles to redress harms done to particular individuals without reinforcing and perpetuating discriminatory classifications in the long or short term. Under the principles offered in this Comment, prohibitions on abusive speech must be applied in a nondiscriminatory fashion to a class of expressions (e.g., sexual solicitations as a whole or personally abusive epithets as a class). The requirement of nondiscriminatory application derives froin the notion that the civility zone protects the targeted individual from unwanted speech rather than serving as a tool to suppress unpopular opinions or ideas.

\section{Flag Burning, the Confederate Flag, and Other "Offensive" Symbols}

In most cases, someone who publicly burns a flag does not "target" her message at any particular person. Even where she directs her protest at a certain group of people (for example, the attendees of the Republican National Convention), 275 she usually intends her act as a protest-at whatever level of specificity-against "the government" or "the United States." The flag signifies the nation as a whole, not a particular group of persons, ${ }^{276}$ and by implication flag burning does not single out any particular individual. The government qua government can liave no legitimate interest in suppressing the flag burner's speech because it would fit the classic model of governmental suppression of any idea that threatens the government's ideology. ${ }^{277}$

The dissent in United States v. Eichman, ${ }^{278}$ however, relied on the government's imterest in the symbolic value of the flag in its attempt to give effect to the flag protection statute which the niajority refused to enforce:

[I]t is now conceded that the Federal Government has a legitimate interest $m$ protecting the symbolic value of the American flag. ... [The flag] has at least these two components: in times of national crisis, it inspires and inotivates the average citizen to make personal sacrifices in order to achieve societal goals of overriding inportance; at all times, it serves as a

relief to traditionally oppressed groups but not to similarly attacked majority group members, "troubling" because it might be used by "by one subordinated person to lash out at another." Id. at 2363.

274. See supra notes $82-92$ and accompanying text.

275. Texas v. Johnson, 491 U.S. 397, 399 (1989).

276. Id. at 405 .

277. See id. at 414-16 ("the Government may not prohibit the expression of an idea simply because society finds the idea itself offensive or disagreeable").

278. 110 S. Ct. 2404 (1990). 
reminder of the paramount importance of pursuing the ideals that characterize our society. ${ }^{279}$

The dissenting opinion could point to no individual harm redressed by punishing protesters who burn fiags as a means of communication. In contrast to the dissent in Eichman, the Seventh Circuit in the Skokie case noted that speech critical of the government cannot be punished under the first amendment because the very fact that "the effective exercise of First Amendnent rights may undercut a given government's policy on some issue is, indeed, one of the purposes of those rights."280

Moreover, even where flag burners direct their protest agamst specific individuals, those mdividuals will likely be government officials. Courts cannot remedy that type of targeting without meeting the high standard of New York Times, which accepted as a policy matter that public officials must accept vitriolic criticism as part of their jobs. ${ }^{281} \mathrm{By}$ assuming public office, they have essentially waived some of their interests in being left alone.

There are, however, very narrow situations in which flag burning could fit into the definition of harm-causing described in this Comment. A flag burner's act can cause harm to mdividuals, but it is harm quite different froin that envisioned by the dissenters in Eichman. It may have severe effects on particular individuals watching sucl an event. Veterans and others have expressed their shock, revulsion, and lorror at the sight of a burning flag. ${ }^{282}$ This second type of harm does not affect the government, but rather those particular individuals who observe the event. This type of harm constitutes injury to the individual qua mdividualnot in her status as a veteran or as a part of America, but harm to the imdividual's sense of safety, personal space, and right to be let alone.

Nonetheless, to be actionable in consonance with the civility zone concept, the flag burner would have to target the imdividual specifically. For example, if a person burned a fiag directly in front of a paraplegic veteran, knowing the veteran would be particularly upset by such a display, the burner would have met the susceptibility test laid out above. While fiag burning im general may be offensive to a great many people, it takes special effort by a fiag burner to single out an individual for harm. Thus, only in an atypical situation could a flag burner come within the

279. Id. at 2410.

280. Collin v. Smith, 578 F.2d 1197, 1205 (7th Cir.), cert. denied, 439 U.S. 916 (1978).

281. New York Times, 376 U.S. at 270; see also Near v. Minnesota, 283 U.S. 697, 718-19 (1931) (public officials inay not abate as a nuisance newspapers that repeatedly publish defamatory articles about public officials because, no matter how inflammatory these articles may be to the public, libel laws provide a sufficient reinedy).

282. A Shift in the Winds Swirling Around Old Glory, U.S. News \& WORLD REPORT, Oct. 30, 1989 , at 14 (veterans collected a million and a half signatures advocating prohibition of flag burning). 
harm-causing definitions of this Comment. Even though the harm depends upon the symbolic significance of the smoldering flag, courts should not prohibit legal redress of this harm to an individual as governmental suppression of expression.

The importance of targeting is even more clear in recent campus controversies regarding the flying of the Confederate flag or the use of other symbols of the Confederacy. ${ }^{283}$ At several campuses, many have objected to some fraternity houses' practice of flying that banner. ${ }^{284}$ To blacks, the flag represents advocacy of a return to slavery; to the whites flying it, it represents their "Southern heritage."285 This dichotony of understanding presents problems of intent and known susceptibility. Although the whites flying the flag in all likelihood know that the flag will offend African American passersby, they may lack the specific intent to harm any particular individual. Moreover, targeting is entirely absent because offended viewers can easily avert their eyes. Speech has not been forced upon thein. This therefore does not constitute a situation in which the flag fliers could be purished under the principles offered in this Comment. If someone flies the offending flag without directing it at any particular person, then the civility zone of the passersby has not been invaded. ${ }^{286}$

Both these situations (burning the United States flag and flying the Confederate flag) raise the same essential question relevant to university anti-slur regulations: what limits are appropriate on symbolic coinmunications that greatly upset some viewers. The rule here should be no different than that which protects and regulates verbal expression. If the speaker targets the expression at an individual who she should know is particularly susceptible to being upset by the communication, then the university may punish the speaker im order to protect the hearer's civility zone and right to be left alone. If, however, the speaker merely stages the offensive symbol or act as a public display or protest and does not target

283. See Note, supra note 3, at 311; see also Melton v. Young, 328 F. Supp. 88, 94 (E.D. Tenn. 1971) (high school regulation prohibiting "provocative symbols on clothing" unenforceable due to vagueness; however, suspension of student for wearing a Confederate flag patch justified in view of prior violence at the school associated with use of Confederate symbols as school emblems), aff'd, 465 F.2d 1332 (6th Cir. 1972), cert. denied, 411 U.S. 951 (1973).

284. See, e.g., Confederate Flags Prompt Sanctions Against Kappa Alpha, UPI Regional News, Apr. 6, 1990 (LEXIS, Nexis library, Omni file) (fraternity barred from reeruiting new members and ordered to attend "diversity and sensitivity" workshop after members wore tiny Confederate flag in defiance of temporary campus ban); Auburn Halts Display of a Confederate Flag, N.Y. Times, Feb. 20,1985 , at A10, col. 6 (university president ordered an all-white fraternity to cease flying a "giant Confederate flag but gave it permission to fly a smaller one").

285. See Note, supra note 3 , at 311.

286. Cf. Khalid Abdullah Tariq al Mansour Faissal Fahd al Talal v. Fanning, 506 F. Supp. 186, 186-87 (N.D. Cal. 1987) (followers of Islam-a population of 600 million-have no defamation claim against the maker of film portraying the brutal execution under Islamic law of an adulterous Saudi princess). 
particular individuals, then a state university may not, consonant with the first amendment, punish the expression.

\section{V}

Conclusion: VAlue Judgments, Rulemakers' INTENT, AND JUDICIAL OBJECTIVITY

Allowing state universities to enforce anti-slur regulations troubles inany people because they see it as the enforcement of a value judgment on the speaker's expression. ${ }^{287}$ While the first amendment's core function is to protect the expression of all opinions, it is naive at best to believe that courts have already excised value judgments from first amendment jurisprudence. For example, the Chaplinsky test as formulated does require a court to decide whether the speaker's words constitute "no essential part of any exposition of ideas" as well as whether the words are inherently likely to cause a violent reaction. ${ }^{288}$ Judges then1selves often comment on the acceptability of the very speech they protect in first aniendmient decisions. ${ }^{289}$ Even such a staunch first amendnient absolutist as Justice Douglas, dissenting in Dennis v. United States, ${ }^{290}$ felt the need to repudiate Communist doctrine, the teaching of which resulted in the petitioners' conspiracy conviction: "Conunumisin has been so thoroughly exposed in this country that it has been crippled as a political force. Free speech has destroyed it as a political party. ... [T]he doctrine of Soviet revolution is exposed in all of its ugliness and the American people want none of it."291

Ironically, this sort of nakedly subjective disapproval is apparent in judicial opinions both protecting and pumshing speech. For example, Justice Holmes tried to minimize any potential danıage resulting from the reversal of Abrams' conspiracy conviction by branding Abrams' behavior "the surreptitious publishing of a silly leaflet by an unknown Inan."292 Conversely, Justice Blackmun supported his view that Cohen could be punished for wearing his "Fuck the Draft" jacket by arguing that Cohen's conduct was too insignificant to warrant first aniendnient protection: "Cohen's absurd and immature antic, in my view, was mainly conduct and little speech. ... As a consequence, this Court's

287. See, e.g., Endangered Speech, supra note 46, at 4, col. 1 (characterizing University of California's policy as "censorship").

288. Chaplinsky v. New Hampshire, 315 U.S. 568, 572 (1942).

289. See, e.g., Abrams v. United States, 250 U.S. 616, 629 (1919) (Holmes, J., dissenting) (referring to defendants' beliefs as a "creed of ignorance and immaturity"); Collin v. Smith, 578 F.2d 1197,1199 (7th Cir.), cert. denied, 439 U.S. 916 (1978) (calling the beliefs of the Nazi marchers "generally unacceptable").

290. 341 U.S. 494 (1951).

291. Id. at 588 (Douglas, J., dissenting).

292. Abrams, 250 U.S. at 628 (Holmes, J., dissenting). 
agonizing over First Amendment values seems misplaced and unnecessary."293 However, requiring a court to make judgments on the value or wisdom of speech not only yields unpredictable results but implicates the core prohibitions of the first amendment. ${ }^{294}$

Unlike the Chaplinsky decision, the doctrine proposed in this Comment requires neither a judgment about nor a ranking of the social value of expression to determine whether the first amendment protects that expression. ${ }^{295}$ The courts may not enforce a ban on any specific word or idea. ${ }^{296}$ The civility doctrine allows the courts to sanction the speaker only when she uses words she knows will peculiarly harass and intimidate the hearer. Thus, courts may only allow sanction of the speaker in the context of personally directed and targeted speech. They may not sanction the same speech directed to a nonsusceptible person or issued, for example, im a broadly distributed leaflet. Unlike ranking, which allows certain broad categories of expression to be censored altogether, ${ }^{297}$ the civility doctrine would permit courts to sanction only that speech which, in context, approaches harassment or verbal "assault."298

Professor Matsuda's justification that racist speech is "wrong"299 is surely one reason that universities have enacted the speech regulations. Universities have made institutional judgments that group-based derogatory epithets are an especially pressing social and campus probleni. Since rulemakers' subjective motivations are generally irrelevant to the constitutionahity of a particular rule, ${ }^{300}$ the rulemakers' belief that group-based epithets are wrong will not invalidate the regulations. However, the state cannot use the "incorrectness" of the epithets to justify constitutionally the restriction. To do so would implicate the generally forbidden state

293. Cohen v. California, 403 U.S. 15, 27 (1971) (Blackmun, J., dissenting). But cf. id. at 15 (Harlan, J., writing for the Court) ("This case inay seein at first blush too inconsequential to find its way into our books, but the issue it presents is of no small constitutional significance.").

294. E.g., Collin v. Smith, 578 F.2d 1197, $1201-03$ (7th Cir.), cert. denied, 439 U.S. 916 (1978).

295. But see Meiklejohn, The First Amendment Is an Absolute, 1961 SUP. CT. REV. 245,262 (stating that the first amendment protects literature and the arts because they have a "social" or "governing" importance).

296. Cf. FCC v. Pacifica Found., 438 U.S. $726,744-49$ (1978) (satirical commentary on radio unprotected, not because certain words are inherently prohibitable, but because broadcast at a tine when children could be expected to be in the audience).

297. Meiklejohn, supra note 295, at 258 (cominunications that are not used as activities of governing "are wholly outside the scope of the First Amendinent").

298. Accord Delgado, supra note 16, at 180 (urging the creation of an independent tort for racial slurs); Sinolla, supra note 3, at 198 (analyzing the government interest in protecting individuals from racist stigma); Note, supra note 3, at 327 (encouraging enactment of legislation similar to title VII to protect university students froin racial harassment).

299. See supra notes $114-16$ and accompanying text.

300. United States v. O'Brien, 391 U.S. 367, $383-84$ (1968); see also City of Renton v. Playtime Theatres, 475 U.S. 41, 47 (1986) (citing O'Brien and holding that legislators' motives in restricting adult theatres were irrelevant so long as a legitimate government interest was served). 
interest in the restraint of ideas. ${ }^{301}$

Another aspect of the problem of rulemakers' intent is the rulemakers' decision to single out certain kinds of harm for redress and not others. The University of California regulation escapes such a problem of underinclusiveness by adding the phrase "[all] terms widely recognized to be derogatory references to ... personal characteristics" to its hist of some categories of abusive words. ${ }^{302}$ The U.C. regulation also does not suffer from the equal protection problenis inherent in a "victim's privilege," which would protect only traditionally oppressed groups from abuse and not members of the majority. ${ }^{303}$ Nor does it suffer from the converse problems of flag burning statutes, which protect only the view (presumably) held by the majority. ${ }^{304}$ Instead, the U.C. regulation on its face protects anyone accosted with personally abusive epithets. The regulation proposed by this Comment eliminates the U.C. regulation's rehance on likely violence in favor of a test based on known or apparent susceptibility of a targeted hearer. Such a functionally defined regulation can honestly be justified as protecting the individual hiberty interest in a civility zone rather than enforcing a social morality judgment.

The doctrine proposed in this Comment is therefore consistent with Justice Harlan's statement in Cohen v. California ${ }^{305}$ that, since "goverunient officials cannot make principled distinctions in this area,"306 " '[w]holly neutral futihties . . . come under the protection of free speech as fully as do Keat's poems or Donne's serinons.' "307 By negative imphcation, where the state can nake principled distinctions between causmg harm to others and free expression-using, for example, the principles developed in this Comment-then it can and should regulate utterances that are not "neutral futilities" but rather verbal assaults.

A test keyed to known exploitation of a known susceptibility in an intimidating context leaves that determination grounded on the targeted hearer's right to be let alone rather than on the government's view of the social utility of particular utterances. Although “[o]ne inan's vulgarity is

301. Terminiello v. City of Chicago, 337 U.S. 1, 4-5 (1949); see also supra notes 237-50 (discussing group libel as, fundamentally, a restriction on the expression of ideas).

302. California Policy, supra note 6.

303. See supra note 273 and accompanying text.

304. See Ely, Flag Desecration: A Case Study in the Roles of Categorizing and Balancing in First Amendment Analysis, 88 HARV. L. REV. 1482, 1502-03 (1975) (flag burning statutes engage in content distinction by proscribing "only ideologically charged acts . . . witl a particular set of ideological outlooks").

305. 403 U.S. 15 (1971).

306. Id. at 25 .

307. Id. at 25 (quoting Winters v. New York, 333 U.S. 507, 528 (1948) (Frankfurter, J., dissenting)) (alterations in original). 
another's lyric," 308 the state should permit no one to harass and assault another even if the weapon of choice is speech rather than knives or fists. 